\title{
Neolithisation of the Aegean and Southeast Europe during the 6600-6000 calBC period of Rapid Climate Change
}

\author{
Bernhard Weninger 1 , Lee Clare 2 , Fokke Gerritsen 3, Barbara Horejs 4 , \\ Raiko Krauß5, Jörg Linstädter 1, Rana Özbal 6 and Eelco J. Rohling 7,8 \\ b.weninger@uni-koeln.de \\ 1 Institute of Prehistory, University Cologne, Köln, DE \\ 2 Deutsches Archäologisches Institut, Orient-Abteilung, Berlin, DE \\ 3 Netherlands Institute in Turkey, Beyoğlu, TR \\ 4 Institute for Oriental and European Archaeology, Austrian Academy of Science, Vienna, AU \\ 5 Institut für Ur- und Frühgeschichte und Archäologie des Mittelalters, Eberhard Karls Universität, Tübingen, DE \\ 6 Koç Üniversitesi, Arkeoloji ve Sanat Tarihi Bölümü, Rumeli Feneri Yolu, Istanbul, TR \\ 7 Research School of Earth Sciences, The Australian National University, Canberra, AUT \\ 8 Ocean and Earth Science, University of Southampton, National Oceanography Centre, Southampton, UK
}

\begin{abstract}
In extension of the recently established 'Rapid Climate Change (RCC) Neolithisation Model' (Clare 2013), in the present paper we demonstrate the existence of a remarkable coincidence between the exact (decadel-scale) entry and departure dates of the Neolithic into/from the Aegean ( 6600/6050 calBC) with begin/end of RCC-conditions.
\end{abstract}

IZVLEČEK - Članek predstavlja razširitev nedavno vzpostavljenega modela neolitizacije v povezavi s hitrimi klimatskimi spremembami - t. i. 'Rapid Climate Change (RCC) Neolithisation model' (Clare 2013). V članku opozorimo na izjemno sovpadanje med natančnimi (v merilu desetletij) vstopnimi in izstopnimi datumi za širjenje neolitika v/iz Egejskega prostora ( 6600/6050 calBC) in začetkom/ koncem razmer hitre klimatske spremembe (RCC).

KEY WORDS - Neolithisation; radiocarbon chronology; Rapid Climate Change

\section{Introduction}

The paper is organised as follows. In Section 1 (Neolithic Dispersal), we provide an overview of archaeological research of the Neolithisation process undertaken in the past decade. As is well known, there is a strong temporal gradient between the earliest appearance of Neolithic lifestyles in the Near East and their spread to other regions (e.g., Europe). Although contemporary archaeological research is now focussing on the accompanying economic, socio-cultural and cognitive transformations, an urgent need remains for continued chronological research.

As we discuss in the first section, we observe an increasingly critical attitude of contemporary research towards the so-called 'wave-of-advance' description of Neolithic dispersal. We address here the three main 'core-elements' of this widely applied model: (1) the basic notion that the expansion of farming from the Near East to Europe can actually be described as a continuously advancing cultural-demographic wave; (2) the specific result that Neolithic lifestyles expanded from the Near East into Europe with an average speed of $\sim 1 \mathrm{~km} / \mathrm{yr}$; (3) the assumption that both (1) and (2) are supported by radiocarbon dating.

In Section 2 (Rapid Climate Change - RCC), we address some results of ongoing palaeoclimatological research. We provide an overview both of regional, mainly lower resolution RCC-records for the Eastern Mediterranean, as well as global high-resolution records, with a focus on the time of the Hudson-Bay outflow. In this section, we also examine some pro- 
blems relating to our previous timing of RCC-periods (Weninger et al. 2009a). These periods were based on the temporal distribution and clustering of major peaks in the Greenland GISP2 [K+]-record (Mayewski et al. 1997). It still now appears possible to define these periods on a wider scale according to the (smoothed) Greenland GISP2 [K+]-record (Mayew$s k i$ et al. 2004). However, a set of historical records for drought and precipitation anomalies in the Eastern Mediterranean during the Little Ice Age (LIA) does not correlate well with the sequence of individual peaks in the GISP2 $[\mathrm{K}+]$-record, at least not for the period 1500-1900 AD. Instead, the two strongest [K+]-peaks $(\sim 1523 \mathrm{AD}$ and $\sim 1640 \mathrm{AD})$ are coincident (within error limits of $\sim 2 \mathrm{yrs}$ ) with the two strongest historically documented dust storms in the north Chinese plains (Hui et al. 2013). In combination, the Eastern Mediterranean and Chinese historical data agree well with recent meteorological evidence (Tubi, Dayan 2012) for the existence of two distinct geographic corridors for the outflow of cold air masses from the polar regions at times of pronounced Siberian High (SH). The first cold air corridor has an easterly direction (over China, directly connected with Greenland via the Westerlies). The second corridor follows a westerly direction (into the Eastern Mediterranean, related to Greenland via changes in major atmospheric circulation modes; e.g., Josey et al. 2011).

Section 3 (Cultural History 6600-6000 calBC) provides a condensed overview of cultural developments in the Eastern Mediterranean (Aegean, Anatolia, Levant) during the RCC study interval. To allow for quantitative errors of present ${ }^{14} \mathrm{C}$-based site chronologies, which are typically in the order of 50$100 \mathrm{yrs}$, this interval is artificially subdivided into an early RCC-phase A (6600-6300 calBC) and a late RCC-phase B (6300-6000 calBC). The results summarised in this section are based on a recently completed study (Clare 2013).

In Section 4 (Chronological Case Studies) we provide a compilation of high-resolution ${ }^{14} \mathrm{C}$-chronologies for the Aegean and Southeast Europe in the Early Neolithic (Southeast European terminology). Altogether, four new chronologies are presented, three of which are for sites in West and Northwest Anatolia (Ulucak, Çukuriçi, and Barcin), and one for a site in northcentral Bulgaria (Džuljunica). In addition, at Dikili Tash (North Greece) and at Sidari (Corfu) we have unique on-site evidence for the hydro-environmental impact of RCC-conditions both in the Northern Aegean (Lespez et al. 2013) and in the southern Ad- riatic (Berger et al. 2014). In addition to the respective site descriptions, this section contains a compilation of archaeological arguments (mainly pottery style comparisons), which further substantiate our conclusion that the spread of farming from the Near East into Southeast Europe proceeded in a step-wise and often delayed manner, with one of the most significant delays of around 500 years visible in the Aegean.

Section 5 (Conclusions) brings the new chronological results into context with ongoing interdisciplinary research. Previously, the majority of $14 \mathrm{C}$-based statistical/mathematical models for Neolithic dispersal (e.g., dates-as-data, wave-of-advance) either concluded, or were already based on this assumption, that early farming spread fastest along the maritime routes. Our conclusion is that at certain times the terrestrial routes were equally rapid. This results from the 'super-fast' dispersal (>1000km in <200yrs) as documented for the spread of the Early Neolithic from the Aegean to Northeast Hungary. This speed is recognisable, already at low dating resolution, but becomes all the more evident from the archaeological case-studies that were performed at a higher dating resolution using the method of Gaussian Monte Carlo Wiggle Matching (Section 4). A similarly rapid Neolithic dispersal $(>5 \mathrm{~km} / \mathrm{yr}$ : minimum average; obtained for <200yrs time-span and for $>1000 \mathrm{~km}$ distance) was previously known only for maritime expansion along the Western and Eastern Mediterranean (Fig. 10) coasts. Indeed, this dispersion is so fast, and is accompanied with such large spatial discontinuities, that it may inhibit (or at least complicate) further applications of the linear (continuous) differential equations typically used in contemporary modelling studies.

In a nutshell, we demonstrate a precise temporal coincidence (within given error limits) and strong social impact of RCC on Neolithic dispersal processes. Our conclusions are based on ${ }^{14} \mathrm{C}$-data combined with insights gained from recent palaeoclimatological research, but above all on archaeological data that are analysed from the viewpoint of modern vulnerability theory.

\section{Neolithic dispersal}

Following the introduction of radiocarbon dating some 50 years ago, the chronology of Neolithic dispersal from its area of genesis in the Near East and Anatolia into Europe is today largely based on ${ }^{14} \mathrm{C}$ dates. Advances in chronology have been achieved 
in: (1) dating precision, which increased from typical values of $\sigma=100 \mathrm{BP}$ (around 1970) to $\sigma=40$ BP today; (2) sample size, which decreased from grams to milligrams; and (3) in the quality of archaeological excavation techniques. Today, the majority of ${ }^{14} \mathrm{C}$-AMS measurements are performed on shortlived ('single event') samples (Ashmore 1999). The scientific progress achieved in ${ }^{14} \mathrm{C}$-dating is also apparent in the size and geographic scope of the archaeological ${ }^{14} \mathrm{C}$-database, which ranges from the few dozen dates that were available to Clarke (1965), through hundreds of dates (Quitta 1967); and now into the thousands (e.g., Breunig 1987; Reingruber, Thissen, 2004; Pinhasi et al. 2005; Biagi et al. 2005; Böhner, Schyle, 2006; Luca, Suciu, 2006; Bocquet-Appel et al. 2012; Furholt et al. 2009; Weninger et al. 2009b; Hinz et al. 2012). The CalPal-database used in the present paper contains 21519 dates for 3239 Epipalaeolithic, Neolithic and Bronze Age archaeological sites from Europe and the Near-East, of which $82 \%$ are geo-referenced (Weninger 2014).

In a recent publication, Stephen Shennan et al. (2013) also studied the introduction of agriculture into Central and Northwest Europe based on insights gleaned from a large archaeological database $(\mathrm{N}=$ $13658{ }^{14} \mathrm{C}$-dates). Their main conclusion, based on the application of the 'dates-as-data method', is that the long-term growth of the European Neolithic population followed an approximately exponential trend, but this was interrupted at certain times by major declines in population size of the order of 30$60 \%$. Based on this observation it is argued that the summed calibrated Neolithic radiocarbon data distributions, which show a number of conspicuous peaks and minima, can be used to deduce corresponding demographic booms and busts. Similar methods were applied to advance the idea that, following an initial boom, the Early Neolithic Linear Pottery culture (LBK) ended with a major population collapse (Shennan, Edinborough 2007). The applied methodology is not convincing. In this specific case study, the CalPal-database used by Stephen Shennan and Kevan Edinborough (2007) indeed had a major focus on the LBK-chronology, but its focus was on the LBK in the Rhineland. It contained minimal amounts of ${ }^{14} \mathrm{C}$-data for other LBK settlement regions, mainly from the Köln-laboratory, and was also incomplete for the subsequent Middle Neolithic period.

The application of the 'dates-as-data' method in paleodemographic studies has been found inadequate for many reasons (Weninger at al. 2009b; Crombé, Robinson 2014; Contreras, Meadows 2014, with further references). In general terms, the problem is the extreme bias of the archaeological ${ }^{14} \mathrm{C}$-database towards natural research variability such that: (a) large numbers of dates are available for few sites, (b) very few dates are available for other sites, and (c) the majority of sites remains undated. Certain geographic regions have been favoured by researchers to the exclusion of others. Finally, (d) there is a strongly unequal geographic distribution of major radiocarbon laboratories (e.g., GrN in the Netherlands; 0xA in Great Britain; many countries have no operating laboratories), and these tended to focus on regional projects. As an example, and certainly not in order to compare the relative importance of any given geographic area (or lab, site, or period) simply by ${ }^{14} \mathrm{C}$-counting, in the CalPal-database there are more ${ }^{14} \mathrm{C}$-dated Mesolithic sites $(\mathrm{N}=69)$ from the Netherlands (mainly: GrN-lab) than there are ${ }_{14} \mathrm{C}$-dated Neolithic sites $(\mathrm{N}=37)$ from the whole of Turkey. When the aim is to achieve higher temporal and modelling sensitivity, in our view, it is advisable to base demographic studies not on ${ }^{14} \mathrm{C}$-counting (of any variable) but directly on archaeological evidence (artefacts, sites, visibility, taphonomic questions) (see Cilingiroğlu 2005; Reingruber 2011).

Nevertheless, an important question at stake is why having made considerable efforts to correct their large ${ }^{14} \mathrm{C}$-database for taphonomic bias - Shennan $e t$ al. (2013) found no evidence of the impact of climate variability on Neolithic dispersal. We argue that this is not due to any inherent (size/scope/source) limitations of the database, but rather to the inability of the dates-as-data method to differentiate between statistical-archaeological ${ }^{14} \mathrm{C}$-noise and the climaticdemographic signal with the required temporal resolution. We illustrate this with an order-of-magnitude estimate. Given that the $8.2 \mathrm{ka}$ calBP event extended over a time-span of $\sim 100-150$ years (Thomas et al. 2007), that the majority of ${ }^{14} \mathrm{C}$-ages in the database were processed on charcoal (i.e. results have a systematic but uncontrolled age-offset of 0 100 years), and that the majority of archaeological ${ }^{14} \mathrm{C}$-ages has a precision well beyond $50{ }^{14} \mathrm{C}-\mathrm{BP}$ (with additional errors following ${ }^{14} \mathrm{C}$-age calibration), it will be virtually impossible to detect the demographic impact of the $8.2 \mathrm{ka}$ calBP (Hudson Bay) event by using only the dates-as-data method. Under controlled conditions (theoretical simulation, random sampling) this a priori expectation has been verified by Daniel A. Contreras and John Meadows (2014) for the period of the Black Death in Europe, 
for which a major population decline is historically documented, as well as for the disastrous crash in the Basin of Mexico following the arrival of the Spanish conquerors.

An example from the Neolithic period with relevance for the present study is provided by the recently published 14C-series from Tell Sabi Abyad (Syria). Using $\mathrm{N}=69$ dates on human bone from six cemeteries, Neeltje Plug et al. (2014) discuss whether the $8.2 \mathrm{ka}$ calBP event is visible in the temporal distribution of these data. All dates from Sabi Abyad were measured by the Groningen-laboratory ( $\mathrm{GrN})$ to a precision of 30-50 BP, so one might assume that the precision and accuracy of the ${ }^{14} \mathrm{C}$-AMS measurements is sufficient to answer the question at hand. Using the method of Bayesian Sequencing, based on the known sequence of cemeteries, the authors attempt to further enhance the dating precision. They conclude that Sabi Abyad was continuously occupied during the $8.2 \mathrm{ka}$ calBP interval.

As illustrated in Figure 1, analysis of these data using the method of 'cross-bar' dispersion calibration appears to suggest the existence of two possible gaps in the sequence; one coincides exactly with the $8.2 \mathrm{ka}$ calBP (Hudson Bay outflow) event, and the second occurs slightly later, at $6100-6000$ calBC. Yet it would be wrong to simply use this to attribute the first gap (for whatever social or climatic reason) to the $8.2 \mathrm{ka}$ calBP event, given that the separation of calibrated age clusters before and after the Hudson Bay event can be explained by the strong lateral pull of the median values of the calibrated probability distributions (along the calendric time-scale) by small plateaus in the calibration curve. Hence, the 'gap' is at least partly an artificial construct of the applied analytical method: when ${ }^{14} \mathrm{C}$-dates are calibrated one-by-one (i.e. assumption-free in terms of sequence or grouping) it is typical for their calendric readings to lock into one or the other of the many pre-defined geometric inversions ('quantum states') of the ${ }^{14} \mathrm{C}$ age calibration curve. Such data clustering as becomes evident from Figure 1 is often seen to occur when analysing ${ }^{14} \mathrm{C}$-data both with the histogram method (on the ${ }^{14} \mathrm{C}$-scale) as well as for summed calibrated ${ }^{14} \mathrm{C}$-ages (on the calendric time-scale). In mathematical terms such effects are due to the (geometric) folding properties of the calibration curve. From a more fundamental (axiomatic) perspective, the data clustering is due to the non-commutative properties of ${ }^{14} \mathrm{C}$ dates (Weninger et al. 2011). Note that similar quantisation effects occur when using the interval method of ${ }^{14} \mathrm{C}$-age calibration, or Baye- sian Sequencing, to some extent even in wiggle matching, although in these approaches the problem is not explicitly visible. We also note in Figure 1 that a pro-gap argument could be formulated on the basis of the fact that the cross-bar method seems to successfully reproduce both the known grouping of data according to individual cemeteries, and the known sequence of cemeteries, without any such assumptions having been entered.

Having evaluated the gap-hypothesis, let us now address an alternative: the continuity-hypothesis. A closer look at Figure1 reveals that only one (if any) of the 69 human burials is reliably dated to the timewindow of the $8.2 \mathrm{ka}$ calBP event. It appears that the continuity hypothesis is an even more artificial construct of the applied analytical method than the gaphypothesis. The procedure of Plug et al. (2014) was to apply Bayesian Sequencing using OxCal 4.2 (Bronk Ramsey 2009) with boundaries set between the ${ }^{14} \mathrm{C}$-data pre-grouped according to cemetery. However, in this case study, the Bayesian Sequencing method is not used to further evaluate the continuity model, which is simply applied, but not tested. Of greater interest from a methodological viewpoint is that the incorporation of archaeological information into the calibration procedure apparently does not lead to an enhancement in dating precision in all cases. At Tell Sabi Abyad, the opposite occurs: due to the above-mentioned quantum-effects, and lacking the possibility of applying external numeric (quantitative) dating information, in a real sense 'the simultaneously most precise and accurate results' are achieved when no assumptions are made at all. This effectively negates the main reason for applying the Bayesian Sequencing method, according to which, in general terms, archaeologists may even incorporate ordinal-scaled ('younger-older') archaeological information into the calibration process in order to optimise dating precision. By applying the crossbar-method, despite its acknowledged insensitivity, we at least become aware of the interpretational difficulties that arise from the strong attraction of the calendric-scale readings of all ${ }^{14} \mathrm{C}$-ages towards pre-established states of quantum chronology.

Before continuing, we note that the second gap in the Tell Sabi Abyad data is curiously coincident with a major sub-structure of the $8.2 \mathrm{ka}$ calBP for the period 8030-7960 calBP in the stable oxygen record from Qunf Cave (Oman). In contrast to the first gap, which may or may not be real, this second gap is better described as an interval with non-artificially low data density. At least, it cannot be explained by 
Fig. 1. Tell Sabi Abyad (North Syria). Upper: ${ }^{14} \mathrm{C}$ scale histogram and calibrated summed probability distribution of $N=6914 \mathrm{C}$ dates on human bone from cemeteries $7,6,5,4,3$ and 1 (Plug et al. 2014) shown (Lower) in context with Greenland GISP2 8180 -record (GICC05-age model) as proxy for the Hudson outflow (Grootes et al. 1993), and with Oman Q5 Qunf Cave $\delta 180$-record (Fleitmann et al. 2007) as proxy for shifts in the position of the Intertropical Convergence Zone (cf. Fig. 9).

Upper: ${ }^{14} \mathrm{C}$-and calendric scale crossbars (68\%-confidence) of the ${ }^{14} \mathrm{C}$-dates indicate separation of the cemeteries into 4 groups (Cemeteries $7,6 / 5,4 / 3$ and 1 ). The conclusion of Plug et al. (2014) that the burial sequence is continuous throughout the $8.2 \mathrm{ka}$ calBP period is not validated (cf. text). Either there is a real gap, or the apparent gap is artificially caused by the folding properties of the calibration curve). Note the complex internal structure of the '8.2ka calBP event' with sub-events at 8220-8140 calBP and 80307960 calBP (indicated by shading) defined according to record comparisons shown in Figure 9.

the shape of the calibration curve, which is reasonably linear in this interval. Interestingly, it appears to separate the data from cemeteries $6 / 5$ and $4 / 3$ (with the one exception of human bone from cemetery 4, as indicated in Figure 1). The second gap may simply be due to chance effects in ${ }^{14} \mathrm{C}$-radiometric dating. Nevertheless, given the high quality of the ${ }^{14} \mathrm{C}$-data, and also since the second gap is equally as long as the first, let us keep its existence in mind for future research. Later, we return to the discussion of the internal structure of the $8.2 \mathrm{ka}$ calBP event at a higher temporal resolution (Fig. 9).

In summary, despite the large number of ${ }^{14} \mathrm{C}$-dates and high sampling quality (single entity bones), we cannot distinguish between the two competing hypotheses. In effect, the burial sequence at Sabi Abyad could be continuous in terms of the sequence of individual burials as well as cemetery level, but there could equally well have been a temporary abandonment of the site during the $8.2 \mathrm{ka}$ calBP event.

We infer from this example that the search for climatic impacts on societies is unlikely to be succes- sful when based on single-site analysis. Therefore, and returning to the issue of Neolithic dispersal, we now turn our attention to the study of the signal enhancement that may be expected from a major expansion of the database. Unfortunately, what we see happening in this case is that - in addition to the anticipated problem of limited temporal resolution - a second analytical complication arises. It is related to the spatial distribution of the archaeological ${ }^{14} \mathrm{C}$ data. We illustrate this spatial, geographic problem in Figure 2 (top left), by comparing a diagram from Ron Pinhasi et al. (2005.Fig. 2) with a re-interpretation of the same data (Fig. 2, top right).

Both diagrams show the earliest arrival dates of the Neolithic at 735 Near Eastern and European sites, relative to the great-circle distance $[\mathrm{km}]$ from Abu Madi (Pinhasi et al. 2005; Supplementary Information). Strongly contrasting with the straight lines used as interpolation method in the original diagram, our reinterpretation (shading) suggests several discrete data clusters. These clusters occur both in the 'horizontal' (along the age-scale) and in the 'vertical' direction (along the distance scale). Closer inspection 
of the corresponding map (Fig. 2) shows that essentially no data are available for Spain or Western France. The database contains few dates for the Alpine regions, very few dates for Southeast Europe, and is also lacking in Northern Europe. Yet these aspects are not the really critical issues, and it is obvious that the clusters and void regions are largely due to the incomplete character of the database. The critical aspect concerns the absences of dates for Southeast Europe at distances beyond $2000 \mathrm{~km}$ from Abu Madi, and notably of Early Neolithic ${ }^{14} \mathrm{C}$-ages prior to $c$. 6600-6000 calBC. Already in general terms, the stepwise character of the age-diagram gives reason to doubt the validity of the "wave-of-advance' model, regardless of whether a straight line (Pinhasi et al. 2005) or smooth polynom (Silva, Steele 2014) is used to trace the dispersal process.

What we observe, formulated in more detail, is (1) an almost complete lack of $\left({ }^{14} \mathrm{C}\right.$-dated) Early Neolithic (EN) sites everywhere in Southeast Europe prior to the 8.6-8.0ka calBP RCC-interval; (2) for the same RCC-interval a large number of ${ }^{14} \mathrm{C}$-dated EN sites on the Greek mainland and in Northern Macedonia; (3) a large number of EN sites in Central Anatolia prior to RCC, but which seem to end at some time within the RCC-interval, and (4), a complete lack of ${ }^{14} \mathrm{C}$ dated sites (all Neolithic periods) for the West Coast of Turkey. Although we presently remain suspicious as to the validity of observations (1)-(3), which could be out of date, they appear worthy of further consideration (as undertaken below). The last observation (4) is simply wrong, or formulated better, an outdated function of the age of the ${ }^{14} \mathrm{C}$-database, which was published in 2005 i.e. prior to the availability of first Early Neolithic ${ }^{14} \mathrm{C}$-data from the West Coast of Turkey ( $c f$. bibliography in CalPal-database; Weninger (2014)). Use of the incomplete Pinhasi et al. (2005) ${ }^{14} \mathrm{C}$-database may explain why Carsten Lemmen and Kai Wirtz (2012) found no significant impact of climate variability on Neolithic dispersal, despite a dedicated search for such an impact and the application of state-of-the-art geographic modelling procedures (cf. Lemmen et al. 2011).

A less fragmentary compilation of ${ }^{14} \mathrm{C}$-dates (Clare, Weninger 2014) provides further information, (A) concerning the reality (or its chance existence) of the 'EN-RCC-gap' in Southeast Europe, and (B) concerning a potential (regional) refinement of the standard-value of $\sim 1 \mathrm{~km} / \mathrm{yr}$ initially derived by Albert $\mathrm{L}$. Ammermann and Luigi L. Cavalli-Sforza (1971) for Neolithic dispersal in all regions of Europe and the Near East. The moment the Neolithic left the Aegean basin, which appears to have occurred not earlier than 6100 calBC, it apparently took little more than 100 years to become established at sites in Serbia, Bulgaria, and Romania, and little more than around 200 years even to have reached the Pannonian Ba$\sin$. We conclude that it is impossible to further refine the standard speed of $1 \mathrm{~km} / \mathrm{yr}$ for wave dispersal in quantitative terms because, simply, the concept of dispersal at a steady mean speed is flawed. Figure 4 provides support for the recently proposed idea that, following its arrival in Central Anatolia, there was a long $(\sim 1000 \mathrm{yrs})$ halt in the Neolithic prior to its further westward spread through the Lakes district into the Aegean (Düring 2013; Brami 2014).

\section{Research history of Neolithic dispersal}

The rapidity of Neolithic dispersal from the Aegean all the way to regions in the northeast of the Pannonian Basin, if only indicated at low temporal resolution in Figure 4, is not unexpected. Similar ideas were frequently advanced in the past. A first significant step away from slow 'wave-modelling' was provided by Jean Guilaine, who proposed in his socalled 'arrhythmic' model that the expansion of agriculture was neither regular nor uniform across; Europe as a whole, but proceeded in leaps (Guilaine 2001; 2003; 2013). Further deviations from 'slow' transmission were demonstrated by João Zilhão for the spread of farming along the Northern Mediterranean coast on the maritime route to the Iberian Peninsula (Zilhão 2001). Similar conclusions were arrived at for Neolithic expansion along the Adriatic (Bia$g i$ et al. 2005; Forenbaher, Miracle 2005; Forenbaher et al. 2013). Taking a route that has recently been termed the 'Marine Epipalaeolithic network' (Linstädter in press), the further distribution process along the Mediterranean coasts also appears to have been quite rapid. This is indicated by the arrival of domesticated species in Andalusia and Portugal as early as at $7.5 \mathrm{ka}$ calBP (Aura Tortosa et al. 2009; Carvalho 2010; Cortés Sánchez et al. 2012). Between the Southern Iberian Peninsula and Northwest Africa, within the so-called the Alboran territory (Linstädter et al. 2012), these innovations were further distributed through pre-existing Epipalaeolithic coastal networks representing forager groups focussed on the use of marine resources. Through what has recently been termed 'Continental epipalaeolithic networks' (Linstädter in press), the local foragers from the west-Mediterranean hinterlands adopted Neolithic inventions and integrated them step-by-step into their way of life. The rapidity of 


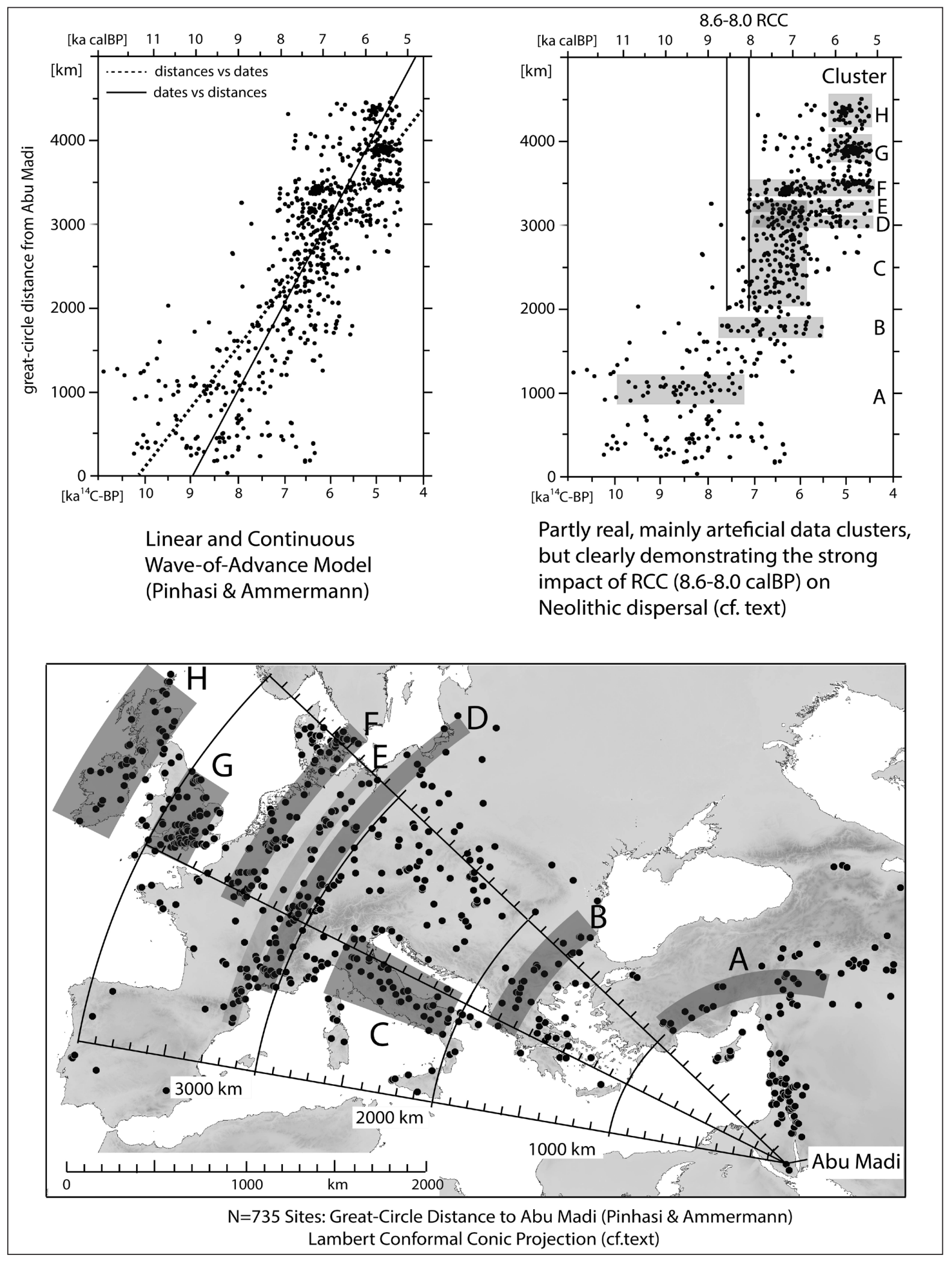

Fig. 2. Map of earliest Neolithic sites according to Pinhasi et al. (2005.Fig. 2), redrawn with Globalmap-

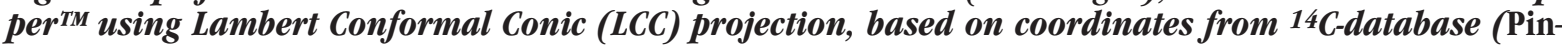
hasi et al. 2005.Tab. 1). Top Left: Age-Distance graph redrawn (unchanged) from Pinhasi et al. (2005. Fig. 2). B. Top Right: Age-Distance graph redrawn (with additional shading to show artificial data clusters A-H) from Pinhasi et al. (2005.Fig. 2). When drawn on LCC projection, a straight line approximates a great-circle route between selected start-and end-points. Note: Pilots use LCC-projection for convenient visualization of flight distances. 
these adoptions is indicated by their equally early date of arrival in Morocco, at around 7.6ka calBP (eastern Rif) (Linstädter, Kehl 2012; Morales et al. 2013; Zapata et al. 2013). However, in comparison to the Eastern Mediterranean, plant cultivation and animal husbandry on the Iberian Peninsula and in North Africa appear to have been only one aspect of subsistence in the sense of a broad-spectrum economy or low-level food production. What is implied by these recent results, and what is important for the present paper, is that there is no evidence in the Western Mediterranean to support an assumption that maritime routes were faster than terrestrial routes of Neolithic dispersal. Although further research is needed, there is wide consensus that the source region for the Neolithic in the Western Mediterranean was somewhere in the Eastern Mediterranean and most probably - in the Aegean. This again emphasises the importance of precisely dating both the earliest arrival of the Neolithic in the Aegean, and its further pattern of dispersal. As yet, it remains unknown whether such datings fall close together (decadal scale), or far apart (centennial scale).

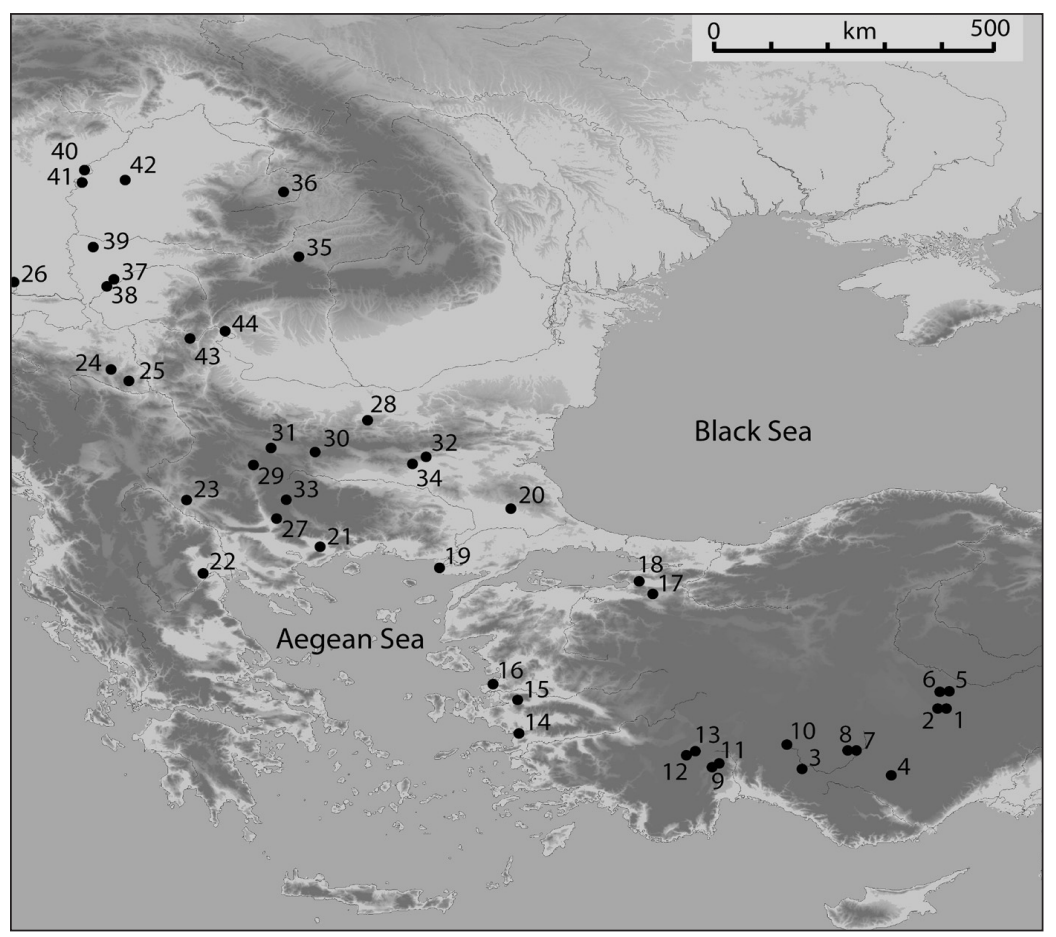

Fig. 3. Distribution of archaeological study sites in Anatolia, Southeast Europe and eastern Central Europe during and after the RCC-interval (6600-5700 calBC). Numbers correspond to site-chronology shown in Figure 4. References for 14C-data: sites 1-20 (Clare, Weninger 2014); site 21 (Lespez et al. 2013); site 22 (Weninger et al. 2006; Linick 1977); site 24 (Tasić 1988); site 25 (Bogdanović 2008); site 26 (Biagi, Spataro 2005; Luca et al. 2008); site 27 (Lichardus-Itten et al. 2002); site 28 (Krauß et al. 2014); sites 29-34 (Görsdorf, Bojadžiev 1966); sites 35-39 (Biagi, Spataro 2005; Luca et al. 2008); sites 40-42 (Oross, Siklósi 2012); sites 43- 44 (Borić 2011).

\section{Rapid Climate Change}

It is now well established that a sharp $8.2 \mathrm{ka}$ calBP climate event developed in response to the abrupt influx of a large volume of meltwater from the Hudson Bay into the North Atlantic. This meltwater outburst resulted in a brief $(<200 \mathrm{yrs})$ disturbance of deep-water formation in the North Atlantic and attendant widespread cooling (Fig. 5). However, the impact of the $8.2 \mathrm{ka}$ calBP Hudson Bay outflow was not only the climate perturbation in this period; it is clearly embedded within one of several Holocene 'Rapid Climate Change' (RCC) intervals (Mayewski et al. 2004; Rohling, Palike 2005; Marino et al. 2009). As shown in Figure 5, the GISP2 non-sea salt (nss) $[\mathrm{K}+]$ record best illustrates this sequence of distinct cooling episodes through the Holocene, as an extension of similar (more intense) events during the last glacial cycle (Mayewski et al. 1997; 2004; Rohling et al. 2002; 2003). Each of these episodes is associated with a more pronounced Siberian High over Asia, which in turn would have led to the increased occurrence and severity of winter outbreaks over Europe and in the Eastern Mediterranean (Mayewski et al. 1997; Cohen et al. 2001; Rohling et al. 2002; 2003; Casford et al. 2003). The existence of recurring cold anomalies during the Holocene is confirmed by a variety of terrestrial and marine records from our study region, the Eastern Mediterranean (Rohling et al. 2002; 2009; Mercone et al. 2001; Meeker, Mayewski 2002; Casford et al. 2003; Marino et al. 2009). Based on the GISP2 nss $[\mathrm{K}+]$ record, the strongest RCCconditions are inferred for the time-intervals $\sim 10.2 \mathrm{ka}$ calBP, $\sim 9.2 \mathrm{ka}$ calBP, $8.6-8.0 \mathrm{ka}$ calBP, $6.0-5.2 \mathrm{ka}$ calBP, and $\sim 3.0 \mathrm{ka}$ calBP (with varying decadel/centennial-scale age-limits). The most recent RCC-event coincides with an episode that is commonly referred to as the Little Ice Age (LIA; c. 1450-1929 AD). Against this RCC background, it appears that the (atmospheric) cold conditions between 8.6 and $8.0 \mathrm{ka}$ calBP were amplified between 8.2 and $8.0 \mathrm{ka}$ calBP by the impacts of the Hudson Bay event 


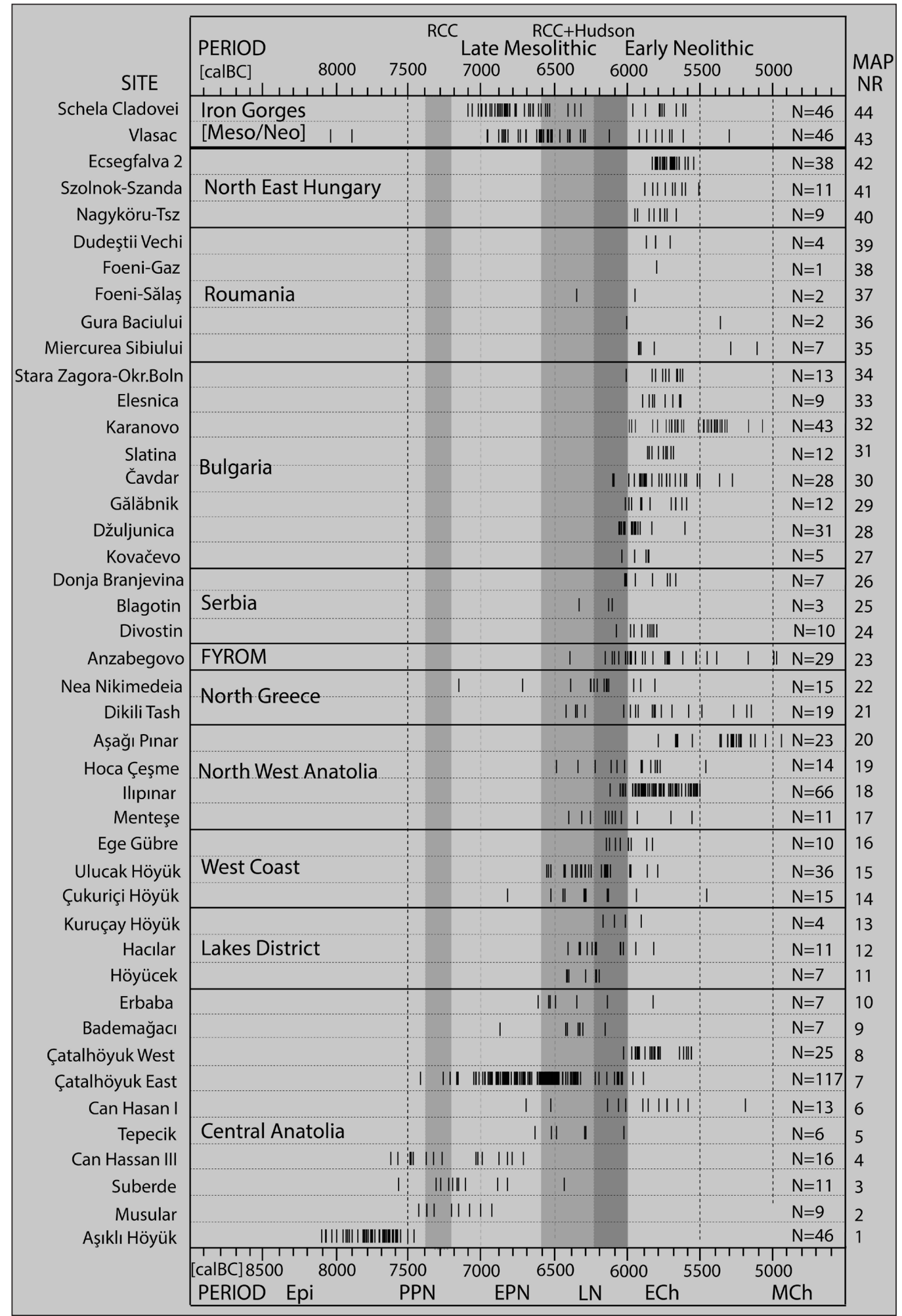

Fig. 4. Overview of $14 C$-ages (total $N=857$ ) for 44 archaeological sites (site numbers refer to the map (Fig. 3), using the Barcode Method of 14 C-age calibration (cf. Time-scales and terminology). Each vertical line represents the calibrated median value of one ${ }^{14}$ C-age, using CalPal-software (Weninger, Jöris 2008) and INTCALO9 calibration data (Reimer et al. 2009). Shaded areas show Rapid Climate Change (RCC) interval 8.6-8.9 ka calBP according to Rohling et al. (2002) and Mayewski et al. (2004), Hudson-Bay outflow interval set schematically to $\sim 6200-6000$ calBC. The position of the $9.3 \mathrm{ka}$ calBP RCC-interval according to Fleitmann et al. (2009) is included for explorative purposes. Abbreviations: Epi = Epipalaeolithic, PPN = Pre-Pottery-Neolithic, EPN = Early-Pottery-Neolithic, $L N=$ Late Neolithic, ECh $=$ Early Chalcolithic, MCh $=$ Middle Chalcolithic, FYROM = Former Yugoslav Republic of Macedonia. From Clare and Weninger (2014). 
(Rohling, Palike 2005; Marino et al. 2009). The combined impacts of the RCC and the Hudson Bay event produced one of the most extreme climate anomalies of the entire Holocene. In the following, we consider the nature of the 8.6-8.0ka RCC impacts on our study region.

\section{Seasonality of RCC}

Strong and cold north-easterly winds in the Aegean are a regular winter/early spring phenomenon. They are of typically short duration of just a few days at a time. In the Eastern Mediterranean, such outbreaks of polar air masses occur most frequently in December, with fewer occurrences in November and January, still lower frequencies in February and March, with the fewest occurrences in October. No polar outbreaks occur in the summer months (Saaroni et al. 1996). The decrease in the number of outbreaks in January is linked to the end of maximum cooling over Eurasia and the associated drop in anticyclone genesis. Concerning their duration, polar outbreaks tend to fall into two categories. The first and most common category is an outbreak lasting between one and two days. Outbreaks in the second category can persist for more than twice as long (Saaroni et al. 1996). We note that the occurrence of such anomalous winter conditions is well known - and feared - in Mongolia (where cold air outbreaks are referred to as $d z u d s$ ) due to their effects on agriculture and livestock mortality (Lau, Lau 1984; Begzsuren et al. 2004; referenced in Tubi, Dayan 2013).

Palaeoclimate records suggest that there were periods during the Holocene when cold air outbreaks over the Eastern Mediterranean were more frequent and/or intense than today. A key record for understanding Holocene RCC-conditions in the Eastern Mediterranean is provided by ${ }^{14} \mathrm{C}$-dated marine microfossil assemblage variations in marine sediment core LC21 from south-eastern Aegean Sea (Rohling et al. 2002; 2009; Casford et al. 2003). This record reveals a series of distinct drops in sea surface temperature (SST) that correlate well (Fig. 5) with periods of enhanced atmospheric dust flux as documented in the Greenland GISP2 glaciochemical record (Mayewski et al. 1997). These SST drops are attributed to the occurrence of north-easterly winds (Rohling et al. 2002; Casford et al. 2003) that, before reaching the LC21 site, would have blown across the surface of the Aegean Sea for several hundred kilometres. The associated cooling $\left(\sim 1-3^{\circ} \mathrm{C}\right)$ of the Mediterranean sea surface (to a depth of $\sim 300 \mathrm{~m}$ ) was sufficiently strong that it contributed to enhanc- ed Mediterranean deep-water formation (Mercone et al. 2001; Casford et al. 2003; Abu-Zied et al. 2008; Rohling et al. 2009).

\section{Rapid Climate Change corridors}

There are two main geographic corridors for the outflow of cold masses from the polar regions at times of pronounced 'Siberian High' (SH) (Tubi, Dayan 2013; with further references). While the first corridor extends westwards from Central Asia, running north of the Himalayas and crossing the North Pontic steppe, eventually entering Southeast Europe, the second corridor takes an easterly path across China and into the Pacific (Tubi Dayan 2013). The westward extension of the SH, on which we focus in the present paper, can lead to continental polar outbreaks over the Aegean, the Adriatic, and the Gulf of Lion (Rohling et al. 2002). These outbreaks are linked to the orographic channelling of polar air masses at the northern Mediterranean margin, more commonly known as the Vardar, Bora and Mistral winds (Casford et al. 2003). Mean annual wind fields over the Mediterranean show a dominance of these northerly outflows (Pinardi et al. 2013/14.Fig. 8), and variations in these systems dominate the spatial pattern of heat loss from the Mediterranean (Josey et al. 2011).

\section{Historical data for RCC in the Eastern Mediter- ranean and China}

As demonstrated by historical data from the recent LIA (Clare 2013), severe winter outbreaks are not the only form of perturbation that would have impacted farming communities in RCC-intervals. Based on historical records from the LIA, it is evident that RCC-conditions in the Eastern Mediterranean are also associated with drought and extreme precipitation anomalies. Although apparently paradoxical, this is simply a reflection of inter-annual variability within a context of significantly increased winter extremes (Clare et al. 2008; Weninger, Clare 2011).

What is in itself quite remarkable is that the historically documented LIA-events (Fig. 6) show a clear clustering of drought years, severe winters, famine and plague, especially in the six decades of the interval 1550-1610 AD. However, what we also observe is that this clustering does not correlate well with the strongest events in the GISP2 $\mathrm{K}+$-record. Notably, the years with highest GISP2 K+-values (1523 and 1640/1644 AD) actually coincide with the 
two strongest historical Chinese dust events (Hui et al. 2013). The in-phase character of the Chinese dust storms with the two strongest GISP2 nss $\mathrm{K}^{+}$ peaks, along with the (seemingly) $\sim 20$ yrs out-ofphase character of Eastern Mediterranean LIA-conditions corresponds well with the existence of the two different RCC-corridors (see above). Notwithstanding these observations, which are at least promising for GISP2 nss K+-based forecasting (at high-resolution) of cold events in China, for the time being we must remain cautious in using the GISP2 nss $\mathrm{K}^{+}$ peaks to forecast individual years with strongest RCC-conditions in the Eastern Mediterranean.

The 8.2ka calBP event: global data (high-resolution records)

Taking a wider geographic perspective, three results of ongoing palaeoclimatological research are of particular relevance to the archaeological $8.2 \mathrm{ka}$ discussion:

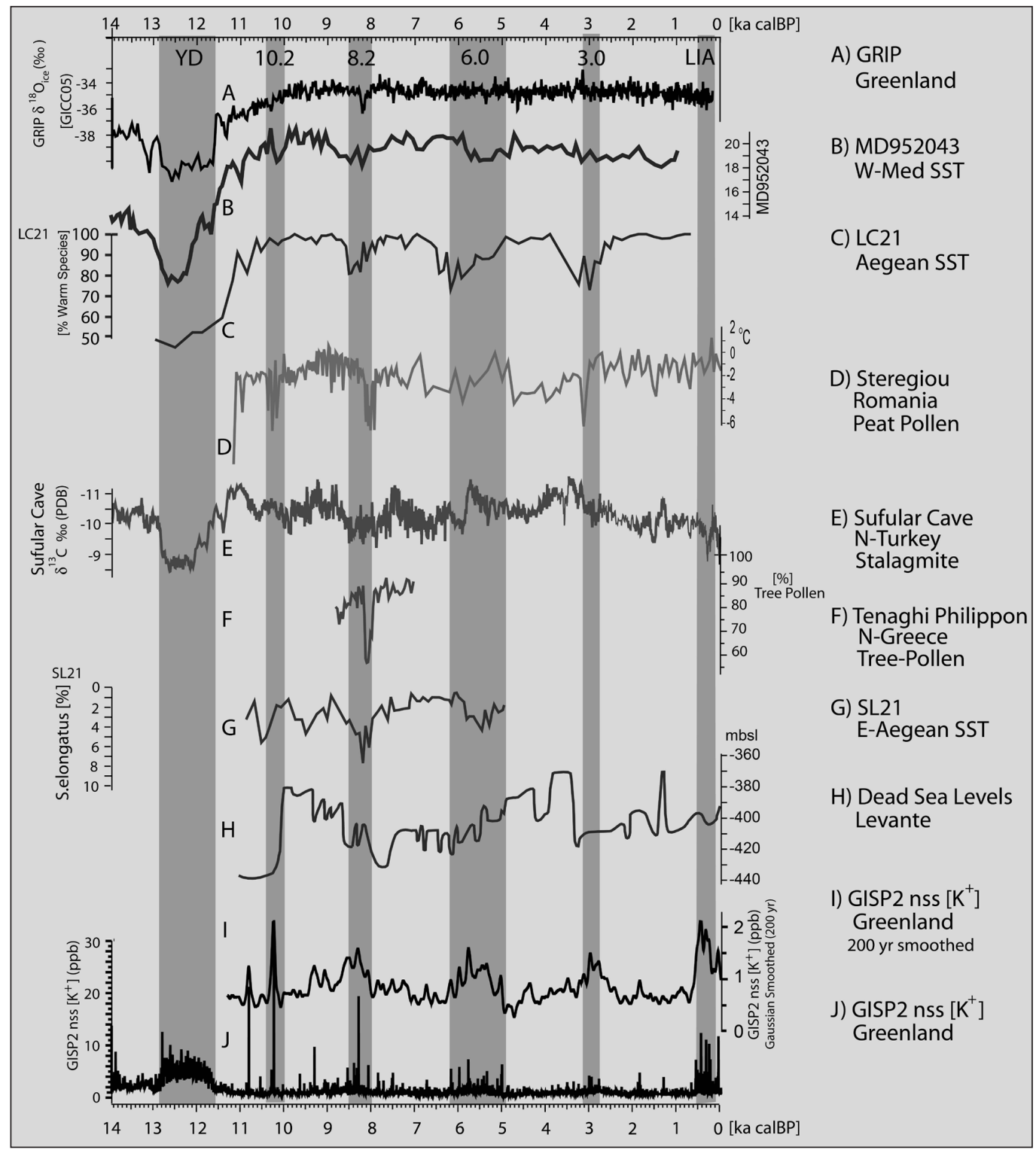

Fig. 5. Northern Hemisphere Palaeoclimate Records showing Holocene Rapid Climate Change (RCC); (A) Greenland GRIP ice-core $\delta^{180}$ (Grootes et al. 1993); (B) Western Mediterranean (Iberian Margin) core MD95-2043; C37 alkenones as proxy for sea surface temperature (SST) (Cacho et al. 2001, Fletcher, Sanchez Goñi 2008); (C) Eastern Mediterranean core LC21 (Sea Surface Temperature, SST) fauna (Rohling et al. 2002); (D) Steregiou (Feurdean et al. 2008; (E) Sufular Cave 813 C (Fleitmann et al. 2009); (F) Tenaghi Philippon tree pollen (Pross et al. 2009); (G) Eastern Aegean SL21 (Sea Surface Temperature, SST) fauna (Marino et al. 2009); (H) Dead Sea Levels (Migowski et al. 2006); (I) Gaussian smoothed (200yrs) GISP2 nss [K+] as proxy for the Siberian High (Mayewski et al. 1997; Meeker, Mayewski 2002); (J) HighResolution GISP2 nss [K+] as proxy for the Siberian High (Mayewski et al. 1997; Meeker, Mayewski 2002). 


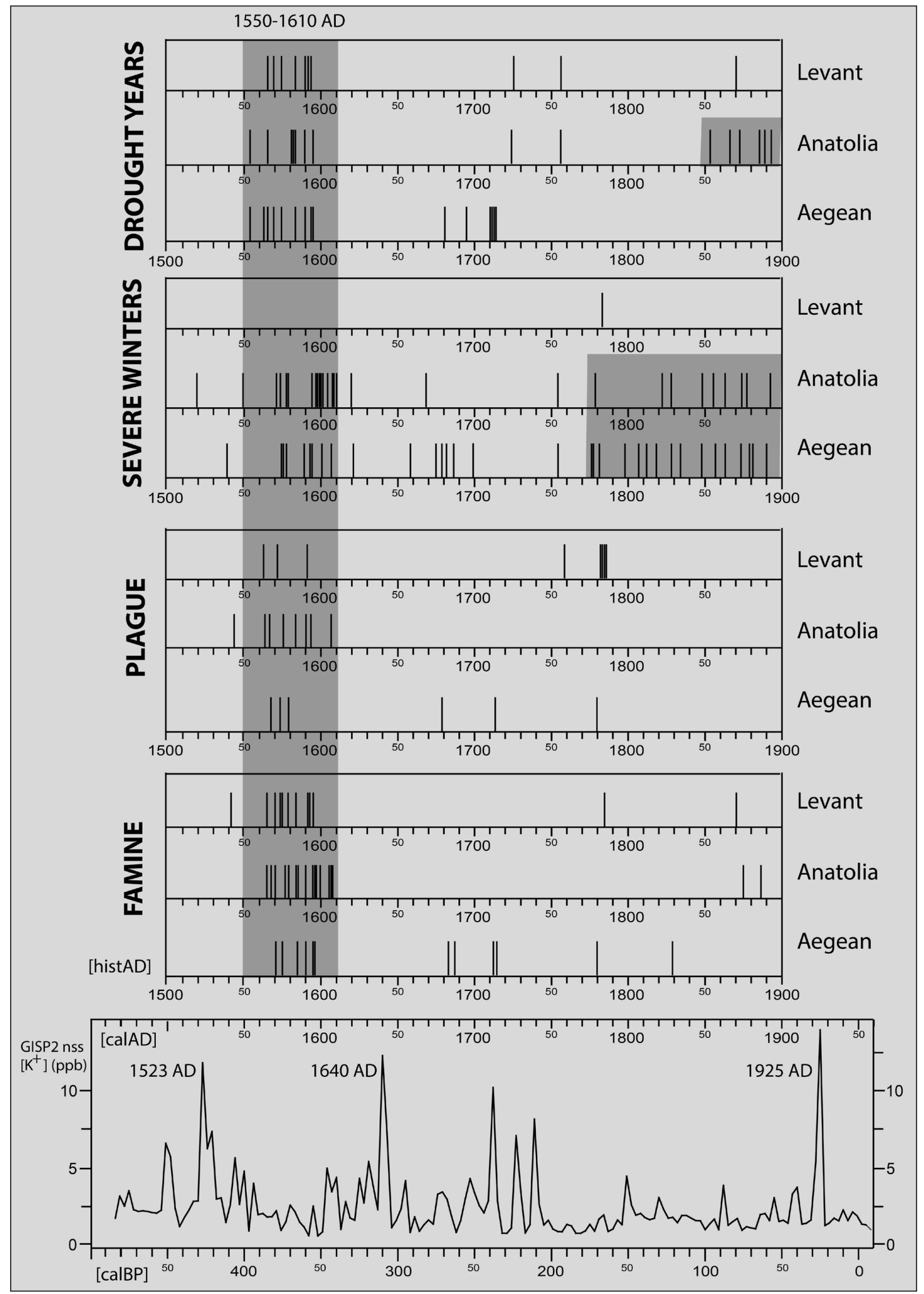

Fig. 6. Compilation of historical records (1500-1900 AD) from different regions of the eastern Mediterranean (Anatolia, Levante, Aegean) with reference of severe winters, drought, plague and famine (data: Clare 2013, with further references and discussion), in comparison to GISP2 nss K+ record (Mayewski et al. 1997). Each historical event is represented by one vertical line. Interpretation: (a) there is clear supraregional evidence of the strongest impact of LIA-conditions in the time-interval 1550-1610 AD; (b), there is no clear (annual-scale) correlation between historical events in the eastern Mediterranean and strongest Greenland GISP2 nss K+ peaks; (c) the two strongest GISP2 nss K+ peaks ( 1523 AD and $\sim 1640$ AD) most likely derive from dust storms documented in the N-China plain (Hui et al. 2013), (cf. Fig. 7). 


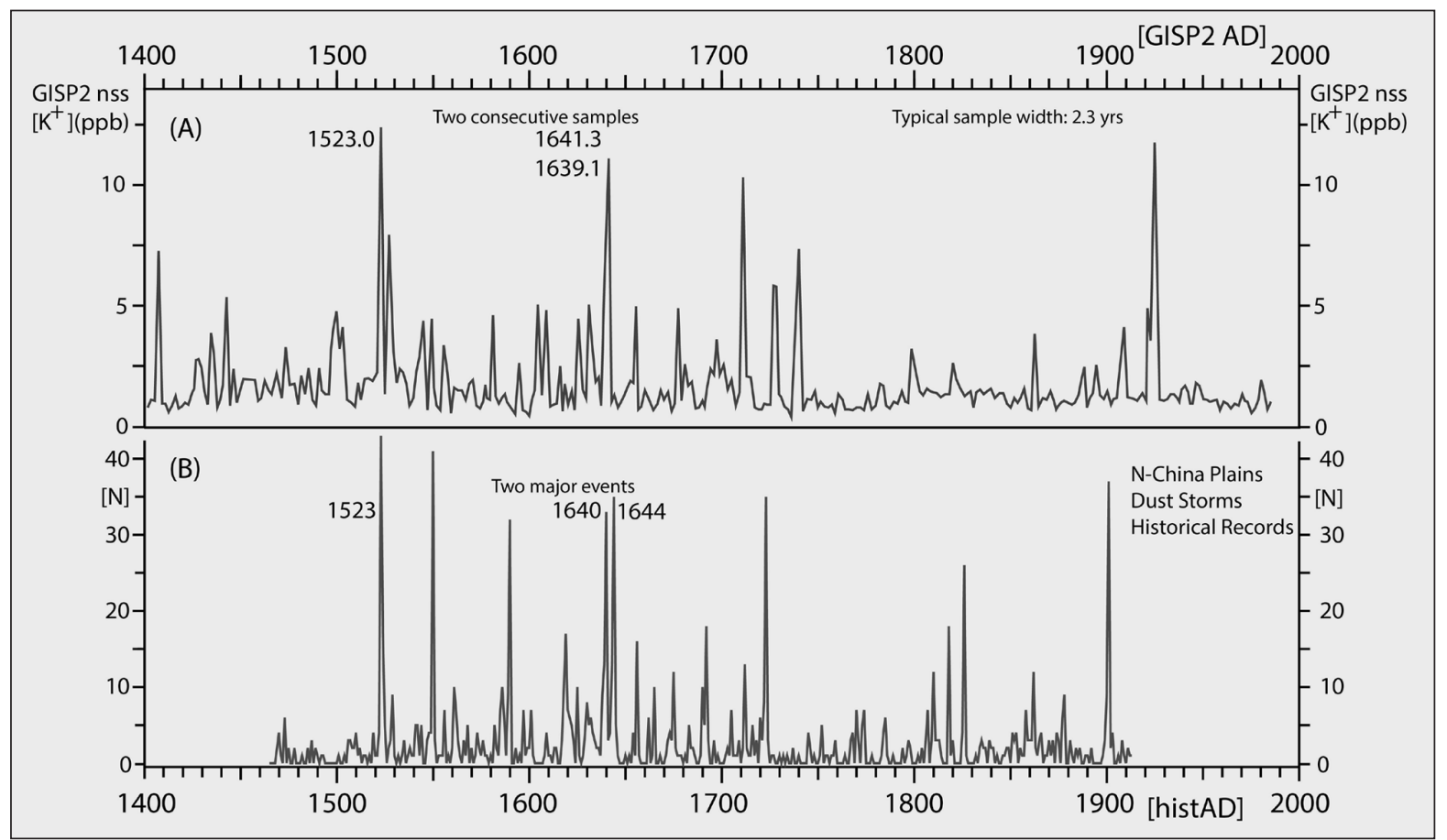

Fig. 7. Dust events in China compared to GISP2 nss K+ climate record. (A) Upper: High-Resolution GISP2 nss $[K+]$ as proxy for the Siberian High (Mayewski et al. 1997; Meeker, Mayewski 2002); (B) Lower: Summed annual frequency of dust storms North China Plain, AD 1464 to 1913, derived from a total of 1180 historical archives (Hui et al. 2013). The 1640/1644 AD double-peak represents the highest number of documented dust storms. The $1644 \mathrm{AD}$ dust storm covered the vast region from $32^{\circ} \mathrm{N}$ to $40^{\circ} \mathrm{N}$. The AD1523 peak relates to a dust storm that was documented in six provinces (Shouzhang, Jize, Yifeng, Dingtao, Fanxian, Weixian). Of all identified dust storms, 72.85\% occurred in the spring, 16.39\% in winter, 8.71\% in summer, and 2.05\% in the auntumn. Hui et al. (2013) relate the spatial pattern of dust storms to the movement of cold air systems in North China in winter or spring.

(1) changes in the strength of North Atlantic ocean circulation are in many details (near) synchronous with climatic variations throughout most of the Northern Hemisphere, including the lower-latitude monsoon regimes of Eastern Asia (e.g., China) (e.g., Rohling et al. 2003);

(2) such long-distance synchronicities are understandable only if they are related via the Earth's atmosphere, and not through oceanic circulation with its comparatively slow (millennial and centennial) transfer times;

3 there are strong indications for a distinctly (almost) anti-phased inter-hemispheric relationship between East Asian and Near Eastern climate regimes on the one hand (i.e. north of the Intertropical Convergence Zone [ITCZ]), and South American climate on the other hand (i.e. south of the ITCZ).

As such, it is not only the North Atlantic climate regime that requires attentive study, but also the interplay between the different components of the global climate system. This is illustrated in Figure 9 for the time-interval 6700-5900 calBC by a compilation of selected high-resolution records that, on the one hand, have their proximity close to the North Atlantic (Greenland and Germany) and, on the other hand, a geographically much wider dispersal from regions as far apart as China, Oman, and Brazil. We note that some records suggest a more complex internal structure within the ' $8.2 \mathrm{ka}$ calBP event', with two major sub-events e.g., 8220-8140 calBP and $8030-7960$ calBP (indicated in Fig. 9 by shading). If the existence of such (very short: decadal-scale) subevents is confirmed, and they impact the Levant, then this would both complicate future climate-archaeological research in the eastern Mediterranean and provide stimulus for further high-resolution studies. Already above, using the ${ }^{14} \mathrm{C}$-data from Tell Sabi Abyad (Fig. 1), we have studied the methodological challenge that the identification of complex substructures of the $8.2 \mathrm{ka}$ calBP event will impose on highresolution ${ }^{14} \mathrm{C}$-dating. Gianluca Marino et al. (2009) offer a first tentative indication that a double peak may exist in the Aegean cool event that appears to be related to the $8.2 \mathrm{ka}$ calBP Hudson Bay event. The relevant climate record (core SL21: E-Aegean SST) is included in Figure 5 (record G). 


\section{Cultural history 6600-6000 calBC}

On the basis of the aforementioned insights from recent palaeoclimatological research, we posit that archaeological climate-culture analysis for the agerange 6600-6000 calBC should consider that the 8.2ka calBP Hudson Bay event occurred embedded within a wider (RCC) cool interval, so that we may recognise an earlier phase (RCC only: 6600-6200 calBC) and a later phase (RCC amplified by Hudson Bay impact; 6200-6000 calBC). The two climate mechanisms would have resulted in similar environmental impacts with a temporal overlap (Rohling, Pälike 2005; Marino et al. 2009). As an alternative to these climate-based phases, but which have unequal length (400 and 200yrs), we can greatly simplify the archaeological discussion (if only for overview purposes with an acceptable loss of chronological precision) by defining two phases of equal length, Phase A (6600-6300 calBC) and Phase B (63006000 calBC).

\section{Phase A: Eastern Mediterranean 6600-6300 calBC}

Major developments in the first phase (RCC: 66006300 calBC) are summarised in Figure 10 (top). In this phase, there is manifold evidence for population movements not only within Anatolia, but also in coastal and lower-lying locations in the Northern and Southern Levant. In the Southern Levant, the onset of RCC $(\sim 8.6 \mathrm{ka}$ calBP$)$ coincides with the first appearance of pottery-bearing communities, commonly referred to as the Yarmoukian culture, and increasing intensities of settlement activities in the coastal plain. These trends coincide with the gradu-

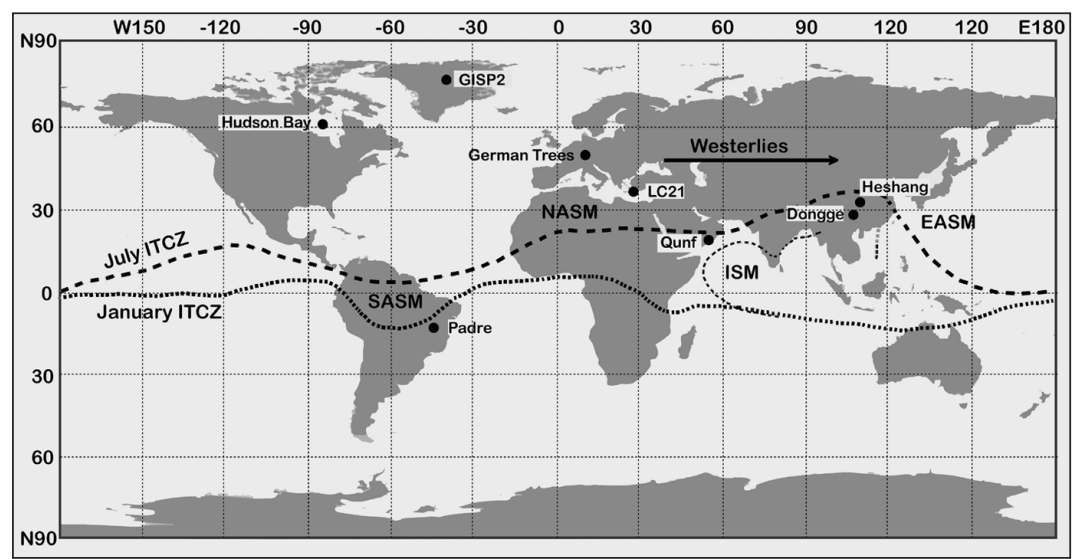

Fig. 8. Modern Position of the Intertropical Convergence Zone (ITCZ) in July and January, redrawn from Cheng et al. (2012.Fig. 1), with location of key sites for records addressed in the present paper. Abbreviations: GISP2 (Greenland Ice Sheet Project Two); SASM (South American Summer Monsoon); NASM (North African Summer Monsoon); ISM (Indian Summer Monsoon); EASM (East Asian Summer Monsoon). al decline of LPPN 'megasites' in the Jordanian Highlands (Gebel 2004). As coastal and lower-lying areas would have been less affected by typical RCC-impacts (e.g., summer drought in combination with severe winters), we posit that the widely observed habitat tracking to milder regions, and in particular (1), from the Jordanian highlands to the Levantine coast, and (2), from the Central Anatolian Plateau to the Turkish West Coast, may be attributed to the same climate mechanism (Clare 2013; with data and references).

\section{Phase B: Eastern Mediterranean 6300-6000 calBC}

Major developments in the second phase (i.e. combined RCC and Hudson Bay event: 6300-6000 calBC) are summarised in Figure 10 (bottom). These were centuries of unprecedented social disturbances in the Southern and Northern Levant, Eastern and Central Anatolia. In the Southern Levant, this phase is referred to as the Late Yarmoukian Crisis (Clare 2013). It sees the widespread abandonment of settlements in the Transjordanian Highlands and the Lower Jordan Valley (south of Lake Galilee), including the major Yarmoukian site of Sha'ar Hagolan. Notably, subsequent Jericho IX culture sites (7900-7600 calBP/ 5900-5600 calBC) are limited to the southern coastal plain, the Jezreel Valley and the Hula Basin. Once again, this trend appears linked to strategies aimed at the mitigation of RCC-impacts.

Eastern Anatolian and Syrian data testify to a similar period of instability, with numerous sites providing either substantial, or at least possible, evidence of settlement abandonment. We have discussed this issue above for Tell Sabi Abyad (Akkermanns et al. 2006; van der Plicht et al. 2011; Plug et al. 2014). Other examples are 'Ain Ghazal, Basta, and 'Ain Rahub (and other sites in Jordan and Israel covered by rubble layers following RCC-related site desertion, see Rollefson 2009; Gebel 2009; Zielhofer et al. 2012); Shir (Bartl 2010), Çayönü (Özdoğan 1999), Akarçay Tepe (Özbasaran, Duru 2011), Aşıklı Höyük (Özbaşaran 2011) and Mersin-Yumuktepe (Caneva, Köroğlu 2010). In the Amuq plain, there is at least a potential hiatus in the ceramic sequence between phases Amuq 


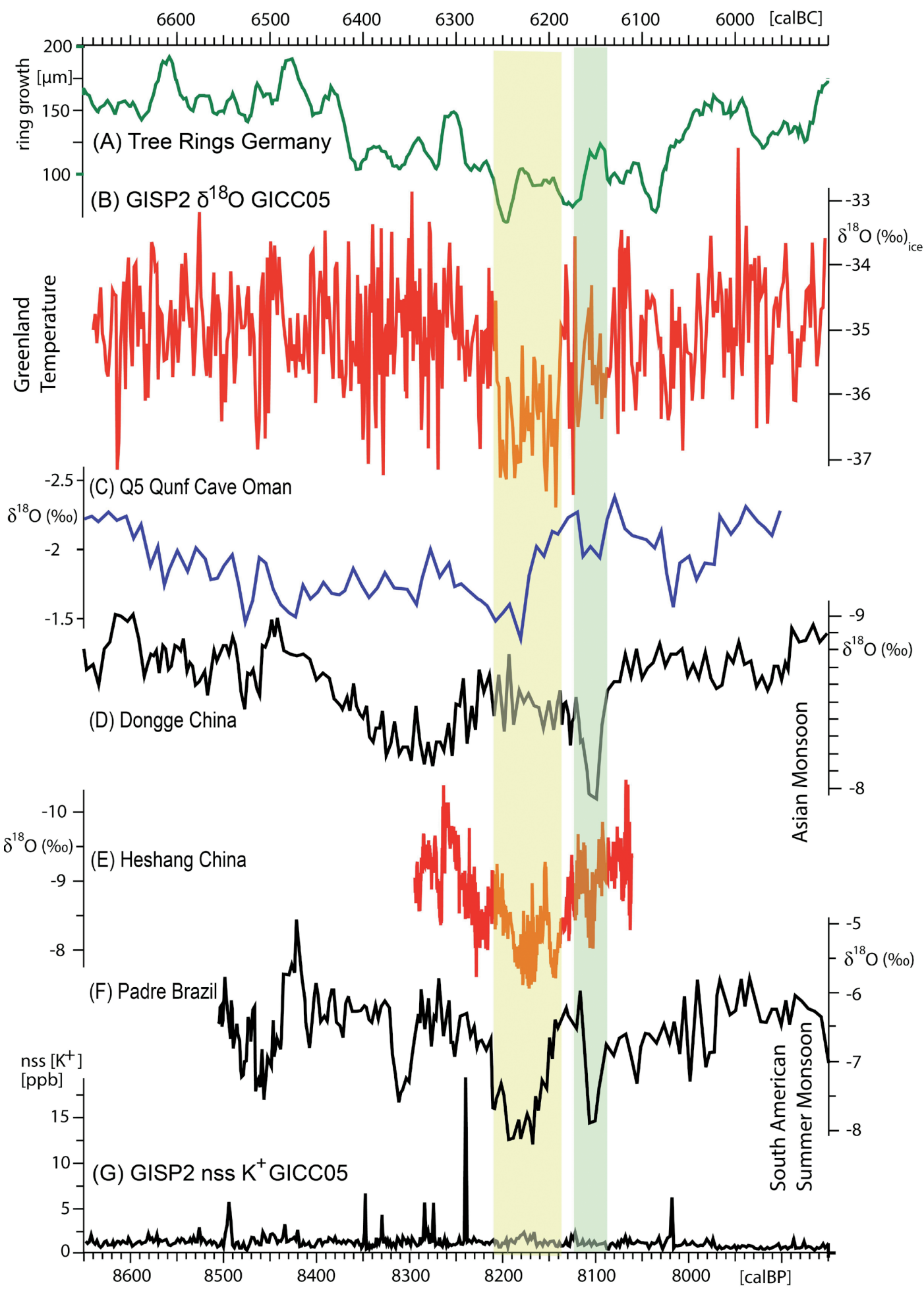

Fig. 9. Timing and structure of the $8.2 \mathrm{ka}$ calBP event on a global scale. Compilation of high-resolution U/Th-dated stalagmite records from China and Brazil (D, E, F) according to Cheng et al. (2009), with additional records $(A, B, C, G)$ added. (A) German oak tree-ring growth record (Klitgaard-Kristensen $e t$ al. 1998); (B) Greenland GISP $\delta^{18 O}$ on Hulu time-scale (Grootes et al. 1993; Weninger, Jöris 2008); (C) Q5 Qunf Cave (Fleitmann et al. 2007); (D) Dongge Cave ${ }^{180}$ (Wang et al. 2001; 2005); (E) Heshang Cave HS4 \$180 (Liu et al. 2013); (F) Padre Cave Brazil 180 (Cheng et al. 2009); (G) Greenland GISP nss K+ on Hulu time-scale (Mayewski et al. 1997; Vinther et al. 2006; Weninger, Jöris 2008). Note the geographic variability and complex internal structure of the '8.2 $\mathrm{ka}$ calBP event' with major sub-events e.g., 8220-8140 calBP and 8120-8090 calBP (indicated by shading). 
A and Amuq B (Balossi 2004), while in the Rouj Basin (Tell el-Kerkh) there is a shift in burial practices, with the first appearance of a demarcated burial ground (cemetery) and central areas in the settlement used for public purposes (Tsuneki 2010). Combined, these data suggest geographically widespread and socially significant changes in prevailing social systems at this time. The westward expansion of farming indicated in Figure 10 (bottom) relies on increasing evidence that the introduction of impresso pottery elements in the Aegean could be related to the arrival of groups from the Northern Levant via

Fig. 10. Top: Summary of events identified in the first phase of RCC (86008300 calBP/6600-6300 calBC) in the Southern Levant and Anatolia (after Clare 2013). There is evidence of a push/pull to coastal and lower-lying locations in both study areas. In Anatolia, this trend is synonymous with the dispersal of Neolithic communities from their core area as far as the Aegean coast. As coastal and lower-lying areas would have been less affected by typical RCC-impacts (drought and severe winters), it is posited that the colonization of these areas would have reduced the biophysical vulnerability of communities to RCC. The disruption in the flow of Cappadocian obsidian to the Southern Levant is quite remarkable. In Western Anatolia, this same commodity was mainly procured from the Aegean island of Melos. This latter development may even testify to breaks with Central Anatolian traditions, and can be interpreted as an attempt to reduce social vulnerability in the face of climate-induced resource shortfalls.

Bottom: Summary of events identified in the second phase of RCC

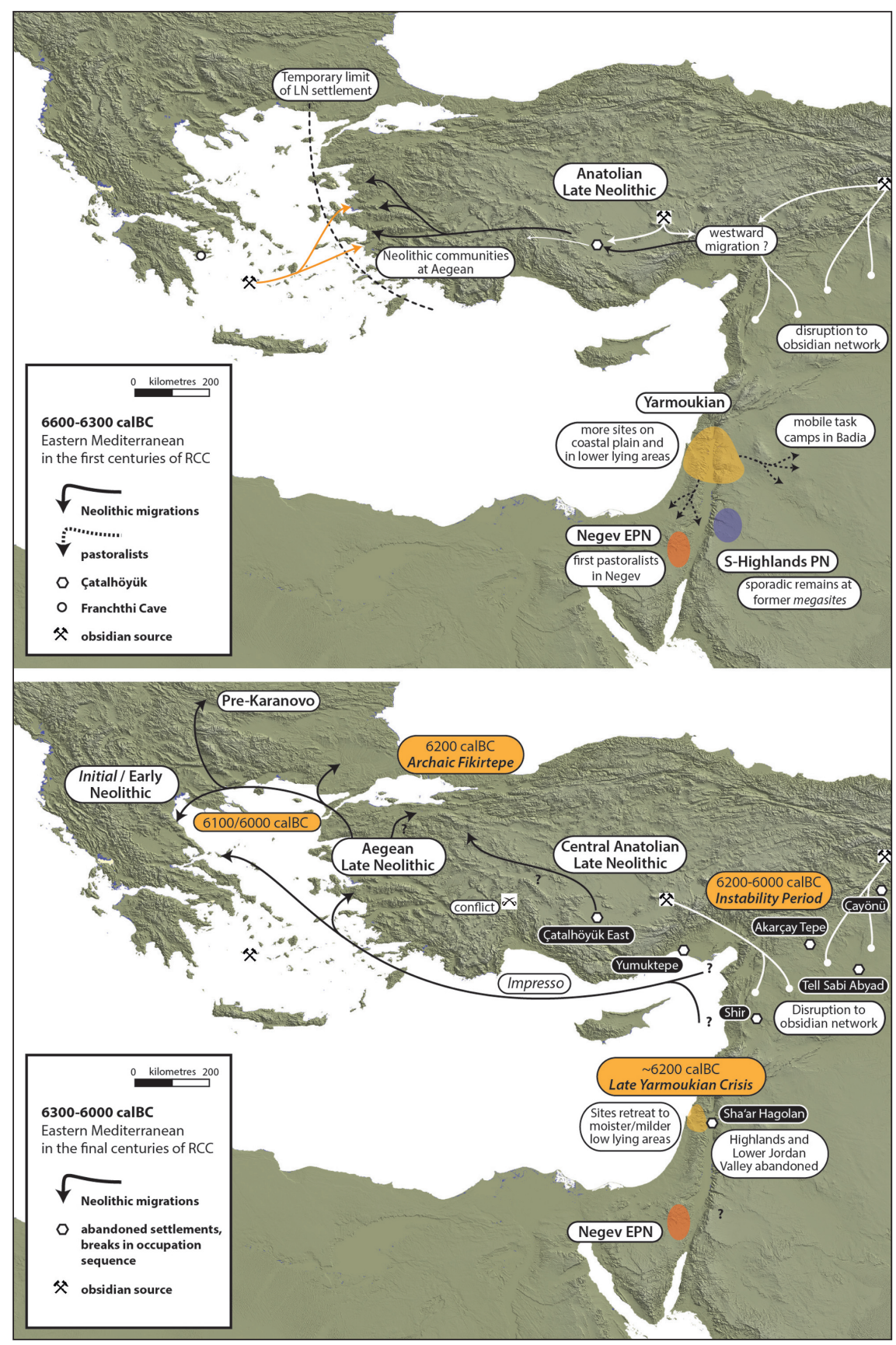
(8300-8000 calBP/6300-

6000 calBC) in the Southern Levant and Anatolia (after Clare 2013). In the Southern Levant there is a further retreat of Neolithic sites to moister (less arid) parts. The related abandonment of sites in the Transjordanian Highlands and the lower Jordan Valley is referred to as 'Late Yarmoukian Crisis'. Remarkably, there are similar developments in the Northern Levant and Eastern Anatolia, where many sites bear witness to an interruption in settlement continuity or are deserted (site names on black background). In the Turkish Lakes District there are first indications for internecine warfare. Curiously, all these developments coincide with a further wave of Neolithic expansion into Southeast Europe. Generally speaking, one of the most astounding aspects of the archaeological evidence reviewed in Figure10 is the increase in cultural (and presumably also demic) mobility in many regions of the Near East and Anatolia. 
a marine route (Cilingiroglu 2010; Brami, Heyd 2011). In this latter region, this development appears to accompany the widespread appearance of Proto-Halaf culture sites (e.g., Cruells 2008).

Before continuing, we note that the traditional assignment of Archaic Fikirtepe (Northwestern Anatolia, Marmara region) to RCC Phase B (Fig. 10, lower) should be treated with caution. This assignment is based on ${ }^{14} \mathrm{C}$-dates from different levels of Yarımburgaz Cave (near Istanbul), which, however, have an unsatisfactory spread, probably due to stratigraphic disturbance ( $c f$. Özdoğan et al. 1991; Clare, Weninger 2014.Tab. 24). As discussed below, new ${ }^{14} \mathrm{C}$-dates as well as stratigraphic and ceramic analyses from Barcin indicate an earlier start of the Fikirtepe culture (in RCC Phase A) and even a pre-Fikirtepe farming presence in the region.

\section{Chronological case studies}

Above, we commented on the abrupt appearance of Neolithic communities in the Aegean at the beginning of RCC-Phase A. It is, therefore, essential that an exact date be established for the very first arrival of farming communities in this region in order to validate (or falsify) the Rapid Climate Change (RCC) Neolithisation relationship proposed in this paper. Specifically, if farming had already been introduced to coastal regions of the Aegean prior to the onset of RCC-conditions, then this relationship would be difficult to support. In this respect, recent excavation results from the sites of Ulucak, Çukuriçi Höyük, and Barcın Höyük, in each case with a new series of stratified ${ }^{14} \mathrm{C}$-dates ( $c f$. below), provide a welcome test of the Aegean-refugium concept as proposed by Clare (2013). Figure 11 shows the geographic location of the archaeological sites under study in the following section.

\section{Ulucak Höyük (Turkish West Coast)}

Ulucak Höyük is located in a plain, bordered to the north and south by mountain ranges, $3 \mathrm{~km}$ east of the Belkahve mountain pass that gives access to the Aegean littoral, some $25 \mathrm{~km}$ further east at Izmir. Ulucak lies on the path of a natural thoroughfare linking the central Aegean coast with more eastern (inland) areas of western Anatolia. The mound currently rises $6 \mathrm{~m}$ above the plain with a diameter of some $100 \mathrm{~m}$, although drilling in the vicinity of the site has shown that settlement probably extended over a much larger area (4.5ha). Sediment accumulations from slope-wash erosion and alluvial depo- sition from the Nif Çayı, a small stream adjacent to the site, has detracted substantially from the height of the höyük, which is known to extend more than 3 metres below the present surface of the plain. Six architectural levels with numerous sub-phases have been identified at Ulucak (Cilingiroğlu et al. 2012). These are, from top to bottom, Late Roman/Early Byzantine (level I), Early Bronze Age (level II), Late Chalcolithic (level III), Early Chalcolithic/Latest Neolithic (level IV), Late Neolithic (level V), and a possible Pre-Pottery Neolithic (PPN) occupation (level VI) (Cilingiroğlu 2011. 68-69).

The stratigraphically derived (age-depth based) results of ${ }^{14} \mathrm{C}$-wiggle-matching) for Neolithic levels VIIV (Fig. 12) provide a chronology with $\sim 400 \mathrm{yrs}$ later foundation of Ulucak (Level VI: $6630 \pm 32$ calBC) than estimated by other authors (e.g., Cakirlar 2012a; b. $~ 7000 / 7040$ calBC), but age differences in similar range are not uncommon for Anatolian and Aegean 14C-chronology (e.g., Rohling et al. 2003). While the excavators describe preliminary discoveries in these lowermost Neolithic deposits (level VI) as reminiscent of PPN features in central parts of Anatolia, a recent evaluation of available radiocarbon ages from associated contexts (cf. Clare, Weninger 2014) would rather suggest an incipient occupation of Level VI no earlier than the late EPN or early LN.

LN occupations at Ulucak (level V) are further differentiated into six different sub-phases, labelled (Vaf). While the oldest subphases (Vb-f) are associated with free-standing wattle-and-daub houses, with three substantial representative buildings in $\mathrm{Vb}$, one of which features a large number of storage facilities (clay bins), the youngest LN sub-phase (Va) is characterised by a change in settlement plan. Houses are no longer free-standing, which is perhaps indicative of an increase in population (Cilingiroğlu 2011.71). It is of note that this phase (Va) also marks the introduction of impressed pottery at the site. Impressed wares appear almost contemporaneously around the Aegean at the end of the $7^{\text {th }}$ millennium calBC, a development that may be linked with the arrival of new groups from the Levant and Northern Syria in the region at this time (Cilingiroğlu 2010).

\section{Cukuriçi Höyük (Turkish West Coast)}

Çukuriçi Höyük (Fig. 11) on the centre of the Western Anatolian coast is located on the Küçük Menderes river delta opposite the island of Samos and is embedded in a sheltered basin that in prehistoric times had direct access to the Aegean. The mound is now visible to a height of $4.50 \mathrm{~m}$ above the plain 
and extends over an area of $80 \mathrm{x}$ $100 \mathrm{~m}$, originally measuring 160 $\mathrm{x} 200 \mathrm{~m}$ and $8 \mathrm{~m}$ high. In the years following the first small-scale rescue excavations in 1995, which recovered evidence for Chalcolithic and Early Bronze Age occupations, the settlement mound was subjected to severe disturbances by modern agricultural activities.

Renewed excavations at the site which commenced in 2006 are now leading to a much clearer picture of the prehistoric settlement sequence at this location (Horejs 2010; 2012). The tell was settled during different periods, with six distinct settlement phases excavated so far, including

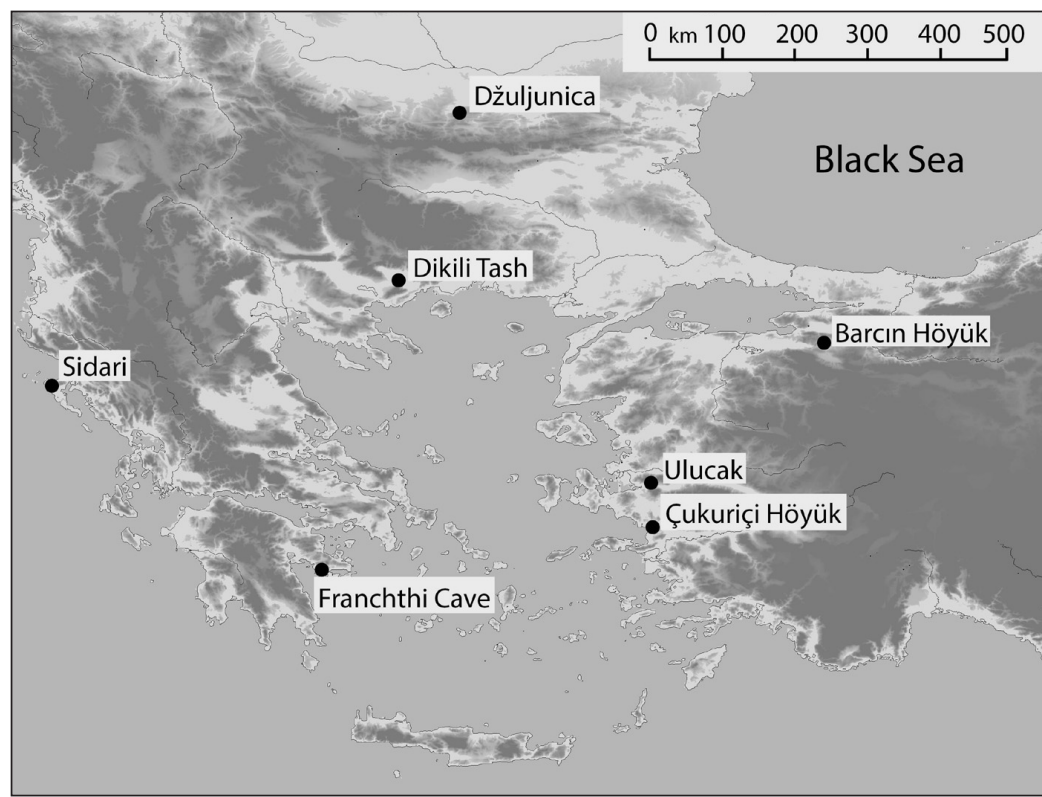

Fig. 11. Geographic distribution of archaeological sites under study in the present paper.
Pottery Neolithic, Early Chalcolithic, Late Chalcolithic and Early Bronze Age periods (Horejs, Weninger in prep.; Galik, Horejs 2011). The earliest excavated settlement phase thus far, Çukuriçi Höyük (ÇuHö) X, revealed rectangular houses with stone foundations and a characteristic Pottery Neolithic assemblage that can be dated to $\sim 6630$ calBC (Fig. 13). The following occupation level, CuHö IX, contains at least one almost complete rectangular building with adjacent open activity zones or courtyards and several other domestic deposits dating between 6400-6200 calBC (Horejs 2012). The following settlement CuHö VIII also revealed the remains of a rectangular building and various domestic settlement structures dated between 6200-6000 calBC (Horejs 2012). The excavated and archaeologically analysed settlement levels are additionally supported by radiocarbon dated drilling cores conducted before the excavation of the Neolithic occupation (Fig. 12).

There are good chances that Çukuriçi Höyük was first settled immediately following the onset of RCCconditions (Fig. 13), similar to Ulucak (Fig. 12), but this hypothesis remains to be tested by ongoing excavations.

\section{Barcin Höyük (Northwest Anatolia)}

Given its potential to elucidate the spread of farming from Anatolia to Southeast Europe and the Balkans, Neolithic research in Northwestern Anatolia has gained tremendous momentum recently, with new projects beginning in the provinces of Bursa, Çanakkale and Istanbul such as Aktopraklık (Karul,
Avcı 2013), Uğurlu (Erdoğu 2013), and Yenikap1 (Kiziltan, Polat 2013) respectively, adding to the existing projects of Fikirtepe, Pendik, Hocaçeşme, Toptepe and Aşağıpınar (Özdoğan 2013). Barcin Höyük, in the Yenişehir Plain south of the İznik Lake and east of Bursa, has contributed to this emerging picture with the earliest evidence of the presence of sedentary farming communities in the region, and new insights into the evolution of regional ceramic technologies (Gerritsen, Özbal and Thissen 2013b). Barcın Höyük (Fig. 11) is a small mounded site with Neolithic occupation levels. Excavations at the site began in 2005 (Gerritsen, Özbal and Thissen 2013a). The Yenişehir Plain is a basin filled with Quaternary deposits with a minor stream (the Kocasu), which drains the valley to the east. Coring with a hand auger around the site indicates a complex history of sedimentary and hydrological changes, dominated by lacustrine and marsh conditions (Groenhuijzen et al. in prep). In addition to the Neolithic Phase, the site has yielded Byzantine, Hellenistic/Roman, Iron Age, Bronze Age, and Chalcolithic phases. Most of these are ephemeral traces and represent intermittent and interrupted occupation throughout these periods. The short habitation sequences in these periods are sandwiched by centennial-scale intervals that lack evidence of human activity of any kind.

Excavations have identified five sub-phases (indicated with the letters a-e) with VIe being the earliest and VIa representing the latest Early Neolithic phase (Gerritsen, Özbal and Thissen 2013a). Soundings have established that the Phase VIe occupation sits 
Fig. 12. (Upper) Ulucak (Turkish West Coast, Levels VIV): Optimised linear stratigraphic 14C-age model based on stratified charcoal ${ }^{14} \mathrm{C}$ ages according to sample depth. Ulucak (Level VI): Monte Carlo Wiggle Matching of short-lived samples based on random Gaussian shuffling of ${ }^{14} \mathrm{C}$-ages $(\mathrm{N}=10000$ iterations) within an interval $0 \pm 20$ yrs. The combined Ulucak age-model is shown in comparison to (Lower): Greenland GISP2 ice-core $\delta 180$ record (Grootes et al. 1993) as proxy for North Atlantic air temperature and LC21 foraminifera data [percent warm species] as proxy for Sea Surface Temperature in the Aegean (Rohling et al. 2002). Allowing for an (error-prone) $20 y r s$ age difference between initial settlement and dated samples, the settlement was founded at $6650 \pm 35$ calBC (95\%), i.e. synchronous with the onset of RCC-conditions (shaded). Note: LC21 age-model has a dating precision of 100yrs (68\%) in this interval. Ulucak ${ }^{14}$ C-data assembled from Cilingiroğlu (2009; 2010; 2011; 2012).

directly on top of a low natural elevation. During phases VIe and VId, the production and use of ceramics increases from 'practically non-existent' to 'rare' and then to 'common' in phase VId (Gerritsen, Özbal and Thissen 2013b). Sharing some very generalised common features with central Anatolian ceramics, the VIe and VId pottery types are best seen as the genesis of a regional northwest Anatolian ceramic tradition that culminates in phases VIc and VIb in the Fikirtepe tradition also known from other sites in the eastern Marmara region. The best preserved architectural deposits come from Phases VIc and VId, which yielded a sequence of row houses surrounded by courtyards. Walls of rectangular houses were constructed from wooden posts set closely together in foundation ditches, providing a skeleton for the mud-covered walls. Adult burials were usually placed within the courtyards, while infant burials, relatively more frequent, have been found in houses, within walls and around oven complexes. Zoo-archaeological analyses show that the subsistence economy was based from the first occupation level onwards on herding and cultivation.
Current evidence provided by the stratigraphy, pottery development and ${ }^{14} \mathrm{C}$-dates for the Neolithic Period (Level VI) suggests a period of about 600 years of habitation between 6600 calBC and around 6000 calBC (Gerritsen, Özbal and Thissen 2013b). This is confirmed in Figure 14 by application of Gaussian Monte Carlo Wiggle Matching based on an explorative equi-length phase model, which was applied independently to the data of the different sub-phases. The validity of this model remains to be established. The existence of a gap (or hiatus) between sub-phases VIc and IVb at the time of the $8.2 \mathrm{ka}$ calBP event cannot yet be excluded, but is not evident in the ceramic sequence or stratigraphy. An intriguing idea - although impossible to substantiate - is that the abandonment of Barcın Höyük and the foundation of Ilıpinar, some $40 \mathrm{~km}$ distant at Lake Iznik, may have been related events. What can be stated with confidence is that the settlement was founded in sub-phase IVe around $6600 \mathrm{calBC}$, or a few decades later if due allowance is made for the dating of potentially long-lived charcoal samples. 


\section{Dikili Tash (North Greece)}

At the Dikili Tash (Fig. 11) site in North Greece, the first detailed on-site geomorphological evidence has been reported for an environmental impact at the time of the $8.2 \mathrm{ka}$ calBP event at high dating resolution (Lespez et al. 2013), as outlined in the following. Dikili Tash is one of the largest tells in northern Greece, covering an area of $\sim 4.5 \mathrm{ha}\left(250 \times 180 \mathrm{~m}^{2}\right.$ at its base) and with a total height of $\sim 22 \mathrm{~m}$, of which $17 \mathrm{~m}$ are above and $5 \mathrm{~m}$ are below the modern surface. Ongoing excavations, which commenced in 1961, have provided a good insight into the long stratigraphic sequence of this settlement, which spans from the Neolithic to the Bronze Age (Treuil R. 1992; Koukoulli-Chryssanthaki et al. 2008; Darcque et al. 2009). In the immediate vicinity of the tell there is a freshwater spring; this fills a pond, which then drains via a streamlet running adjacent to the eastern side of the tell (Lespez et al. 2013. Fig. 1). Of interest for the present paper is the observation that the $8.2 \mathrm{ka}$ calBP event is marked at Dikili Tash by an abrupt rise in ground-water level in this hydrological system, which ultimately led to the relocation of the early Neolithic settlement (Lespez et al. 2013). Given their importance for our RCCrelated studies, we briefly review these inferences. The rise in water level is documented in two cores (core C2 and core C3), but we focus here only on C3 from the northern part of the tell, for which a series of stratified ${ }^{14} \mathrm{C}$-ages is also available (Lespez et al.
2013. Tab. 2). Core C3 shows an approximately $10 \mathrm{~m}$ long sedimentary sequence that extends from the Pleistocene, through the Early and Middle Neolithic, up to the Late Neolithic I and II periods (Lespez et al. 2013.Fig. 3). We concentrate on the earliest Neolithic layers. Starting with Pleistocene clay at its lower end, the core shows a sequence of archaeological layers with Early Neolithic artefacts (e.g., bone fragments, small flakes, one red-brown burnished sherd, and a semi-circular end-scraper). Some of the layers appear to be disturbed, whereas others seem to be in situ. The EN-sequence is interrupted at $\sim 53-54 \mathrm{~m}$ asl by a series of palustrine silts and oncolithic sands (schematically illustrated in Fig. 15, top). Having established by Gaussian Monte Carlo Age-Depth Wiggle-Matching (Fig. 15, top) that the sediment accumulation in C3 is linear (with average growth rate of $2.55 \mathrm{yrs} / \mathrm{cm}$ ) for the study-interval $6400-5600 \mathrm{calBC}$, it is possible to analyse the corresponding sedimentary sequence (Fig. 15, top) in relation to the GISP2 180 record (Fig. 15, bottom).

The timing of the Hudson Bay outflow relative to the sedimentary sequence of core C3 (Fig. 14) supports the concept of Laurent Lespez et al. (2013) concerning an abrupt rise of the ground-water level at the time of the $8.2 \mathrm{ka}$ calBP event. With the age-depth model shown in Figure 14, we note two important details, namely (1) that the rise of ground water level coincides very closely (within error limits <

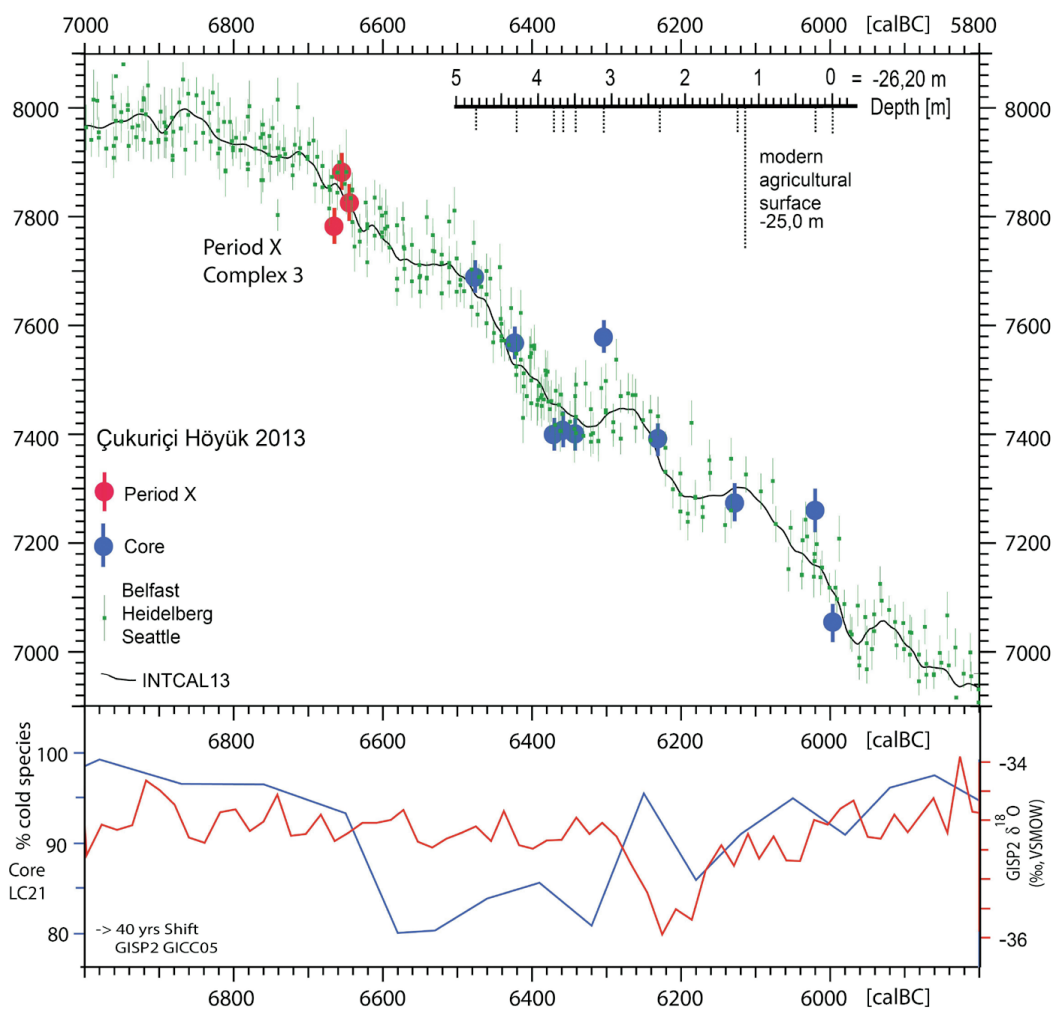

Fig. 13. (Upper): Cukuriçi Höyük (Turkish W-coast). Stratigraphic age-depth model based on geomorphological coring by Helmut Brückner (University Cologne, Department of Geography) at the west edge of the tell. The deepest 14C-age (charcoal: UGAMS-6043; Horejs, Weninger in prep.) is from lowermost cored archaeological deposits. Period X ${ }^{14}$ C-Data: Monte Carlo Wiggle Matching of shortlived samples based on random Gaussian shuffling of ${ }^{14} C$-ages ( $N=10000$ iterations) within an interval 0 $\pm 20 y r s$. (Lower): Greenland GISP2 ice-core $\mathbf{8 1 8 0}$ record (Grootes et al. 1993) as proxy for North Atlantic air temperature and and LC21 foraminifera data [percent warm species] as proxy for Sea Surface Temperature in the Aegean (Rohling et al. 2002). 14C-Data: Horejs, Weninger in prep.; CalPaldatabase (Weninger 2014). 


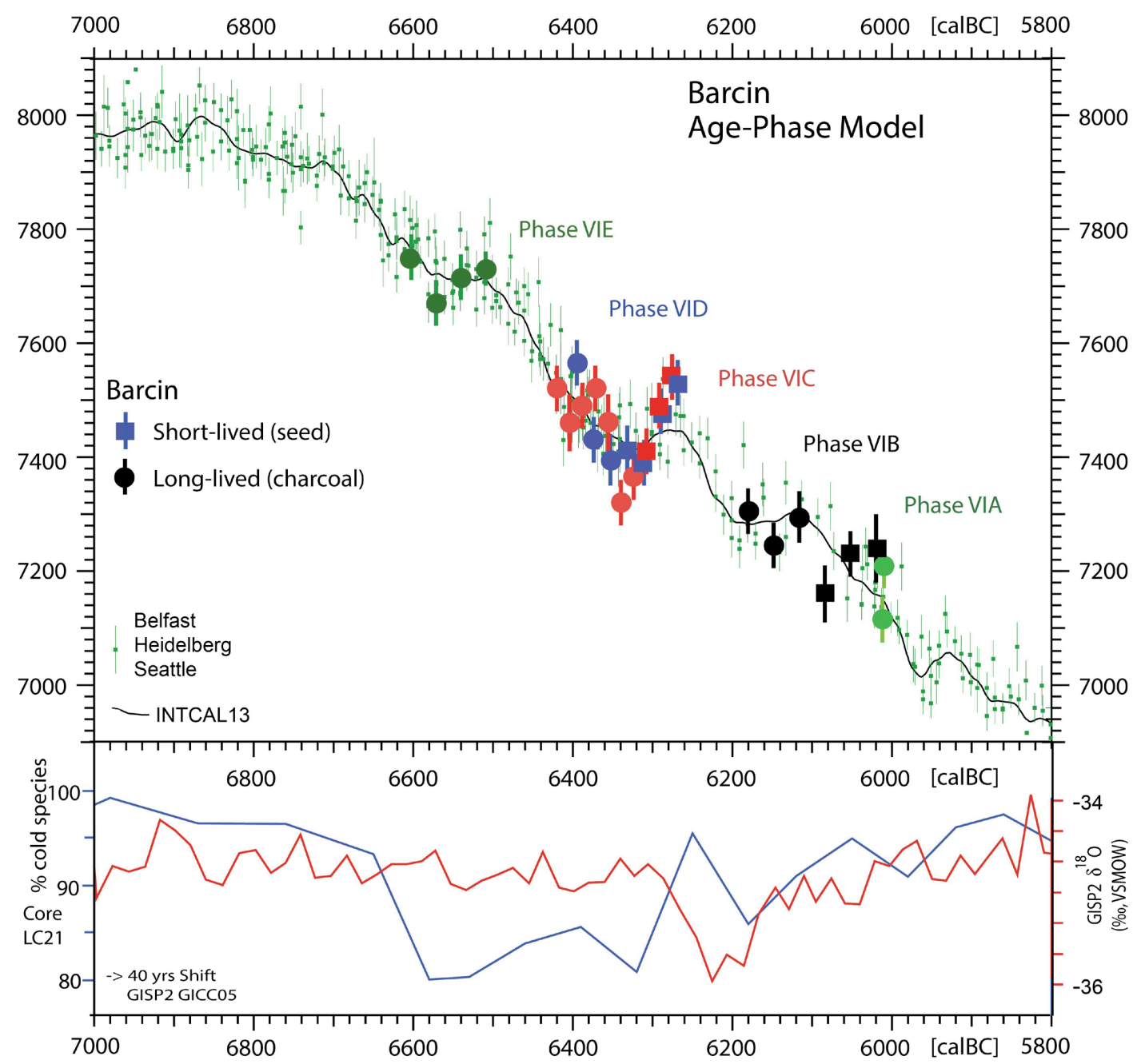

Fig. 14. Barcin Höyük (Northwest Anatolia). (Upper): Explorative equi-length phase-model, established by independent analysis of the ${ }^{14} \mathrm{C}$-dates from sub-phases IVa-VIe, shown in context (Lower) with

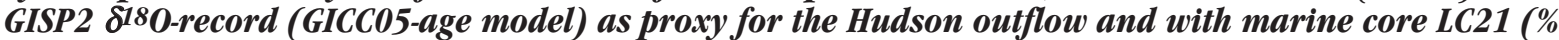
cold species) as proxy for RCC-conditions in the Aegean. The existence of a gap (or hiatus) between subphases VIc and IVb in parallel to the $8.2 \mathrm{ka}$ calBP event cannot yet be excluded, but is not evident in the ceramic sequence or stratigraphy. Hence the temporal overlap of ${ }^{14} \mathrm{C}$-dates from sub-phases VId and VIc is likely to be the artificial outcome of applied modelling procedures. ${ }^{14}$ C-Data: Gerritsen, Özbal and Thissen 2013b; CalPal-database (Weninger 2014); with (outlier) Beta-340889 removed.

$100 \mathrm{yrs})$ with the onset of the $8.2 \mathrm{ka}$ calBP event, and (2) that the site was already occupied (if perhaps only by a few decades) prior to the onset of the $8.2 \mathrm{ka}$ calBP event. The necessity for settlement relocation due to the rising ground water level is also confirmed by ${ }^{14} \mathrm{C}$-ages from Core 2 from a location closer to the site's pond and water courses (Lespez et al. 2013.Tab. 2).

Lespez et al. (2013) further address the question as to why RCC-conditions at Dikili Tash are accompanied with a rise in ground-water level. Based on temperature and precipitation values from pollen transfer functions at the nearby (former) swamp at Tenaghi Philippon (Peyron et al. 2011), Lespez et al. (2013) argue that a reduction in evapotranspiration during the $8.2 \mathrm{ka}$ calBP interval due to a large estimated decrease in winter $\left(\sim 4^{\circ} \mathrm{C}\right)$ and summer $\left(\sim 2^{\circ} \mathrm{C}\right)$ temperatures coincided with a rise of $75 \mathrm{~mm}$ in summer rainfall. This combination would have sufficed to generate high ground-water levels. The interpretation that the $8.2 \mathrm{ka}$ calBP interval experienced colder than normal winters and wetter than normal summers (Peyron et al. 2011) seems to be supported by an increase in Gramineae (grasses) and Cyperaceae (sedges) at the Tenaghi Philippon swamp (Pross et al. 2009).

\section{Sidari (Corfu)}

Another hydro-climatic phenomenon for the $8.2 \mathrm{ka}$ calBP interval was recently observed at Sidari on the island of Corfu (Fig. 11), where flooding and deep 
Fig. 15. Dikili Tash (North Greece). Linear Age-Depth Model for ${ }^{14}$ C-dates from Core 3 (Lespez et al. 2013. Tab. 2; Fig. 3) shown in context with GISP2 8180-record (GICCO5-age model) as proxy for the Hudson outflow. Due to the occurrence of oncolithic sands in Core 3 at depths 53-54m asl the authors identify a rise in groundwater level of a site-adjacent pond. This appears to be a local response to the $8.2 \mathrm{ka}$ calBP event, causing a settlement relocation to dryer parts of the tell (Lespez et al. 2013). Note that the uppermost $14 \mathrm{C}$-age SacA-22588: 6210 \pm 35 BP from core 3 at depth 56.33-56.15m (Lespez et al. 2013.Tab. 2) is removed from analysis as outlier (in respect to the assumed linearity).

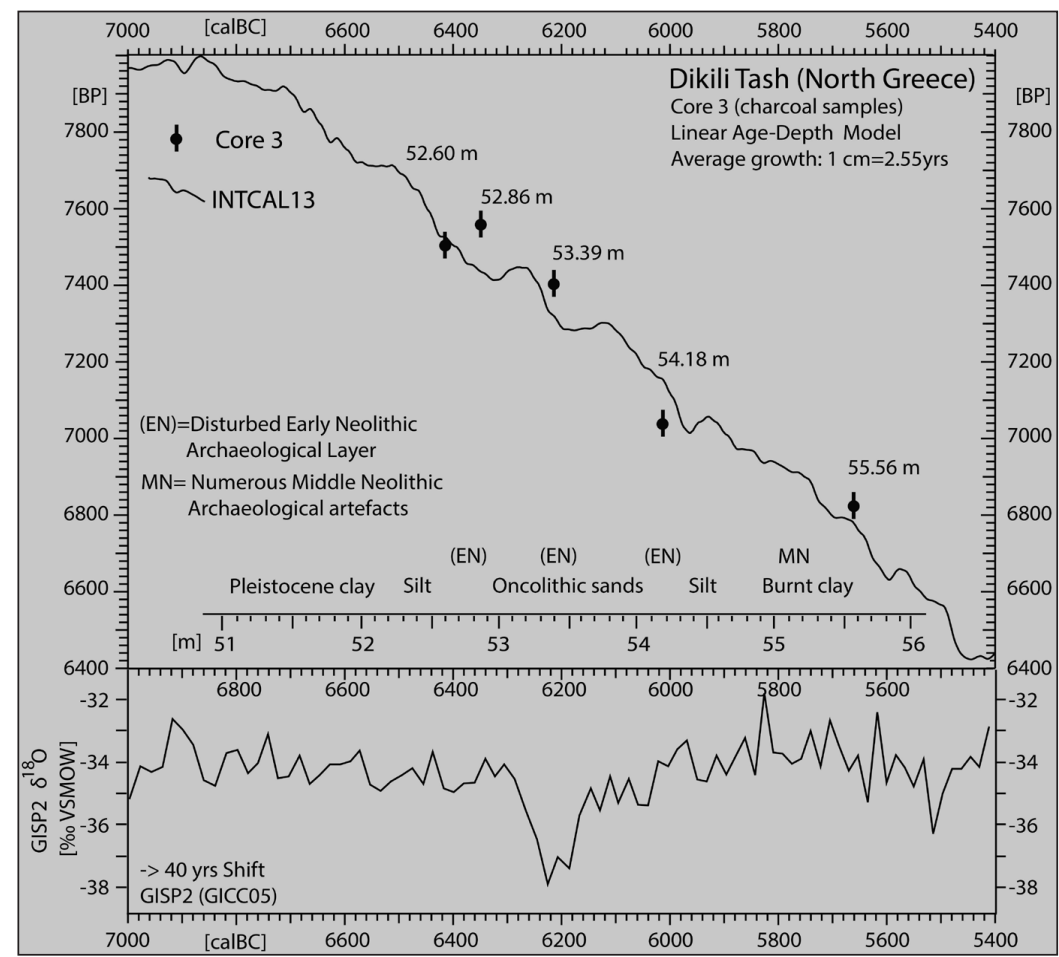

fluvial flows are documented on-site during the transition from an Initial to an Early Neolithic settlement phase (Berger, Guilaine 2009; Berger et al. 2014). At this site, a lower Mesolithic level (layer D) is covered by deposits attributed to an 'Initial Neolithic' (layer C, basis: badly fired pottery, little decorated, indications of the breeding of small ruminants), which is followed by a sterile deposit (hiatus) that, in turn, is overlain by 'Early Neolithic' deposits (layer $\mathrm{C}$, upper part) with characteristic Impressed Ware of Adriatic type. As indicated by the ${ }^{14} \mathrm{C}$-dates (Berger et al. 2014.Fig. 6), all these layers are chronologically so close together that they cannot yet be clearly separated using the available ${ }^{14} \mathrm{C}$-ages (values range between 8000-7670 $\mathrm{BP}$ for the Mesolithic-Neolithic transition, and 7500-7170 BP for the transition between the two Neolithic layers). Importantly, but in need of further validation, Sidari is similar to Dikili Tash in that it records a switch to moister conditions with distinct hydro-sedimentary impacts for the $8.2 \mathrm{ka}$ calBP interval. Combined, the studies of Laurent Lespez et al. (2013), Jean-François Berger et al. (2014), Jorg Pross et al. (2009) and Odile Peyron et al. (2011) define an important milestone for understanding the interplay between (global) climatic change and local hydrological conditions during the $8.2 \mathrm{ka}$ calBP interval.

\section{Franchthi Cave (Argolid, Greece)}

We conclude the Aegean section of this paper by noting that essentially identical results (i.e. $\sim 6600$
calBC) for the arrival of early farming on the Turkish West Coast have recently been obtained by $\mathrm{Ca}$ therine Perlès et al. (2013), using direct 14C-AMS dating of domestic seeds at Franchthi Cave (Argolid, Greece) (Fig. 11). The relevant ${ }^{14} \mathrm{C}$-dates are GifA1106: $7805 \pm 40$ BP and GifA-11455: $7740 \pm 50 \mathrm{BP}$ for sample FAN163, and GifA-11017: 7780 $440 \mathrm{BP}$ and GifA-11456: 7645 550 BP for sample FAN162 (Perlès 2013.Tab. 1). Since all four measurements are statistically identical (Chi-square test: $7.6 \%$ ) on the ${ }^{14} \mathrm{C}$-scale, it is not possible to define an age difference for the two samples on the calendric timescale. Although it is strictly speaking pointless to base any kind of inference on the weighted average for the given (non-commutative) ${ }^{14} \mathrm{C}$-ages, for convenience (in talking about these dates), we nevertheless calculate an average age of $6580 \pm 40$ calBC (i.e. $\sim 6600$ calBC) for these samples. What is important is that there is no measurable age-difference between the earliest (known) date of arrival of the Neolithic at Franchthi and for the Turkish West Coast.

\section{Džuljunica (North-Central Bulgaria)}

Regarding the further dispersal of Neolithic lifestyles into Southeast Europe, key information may be obtained from north-central Bulgaria and the Early Neolithic settlement of Džuljunica (Fig. 11). The location contains natural springs that flow from the base of the prominence upon which the site is located. Even today, there are four active springs at the foot of the site. The prominence itself is a slightly elevated ri- 


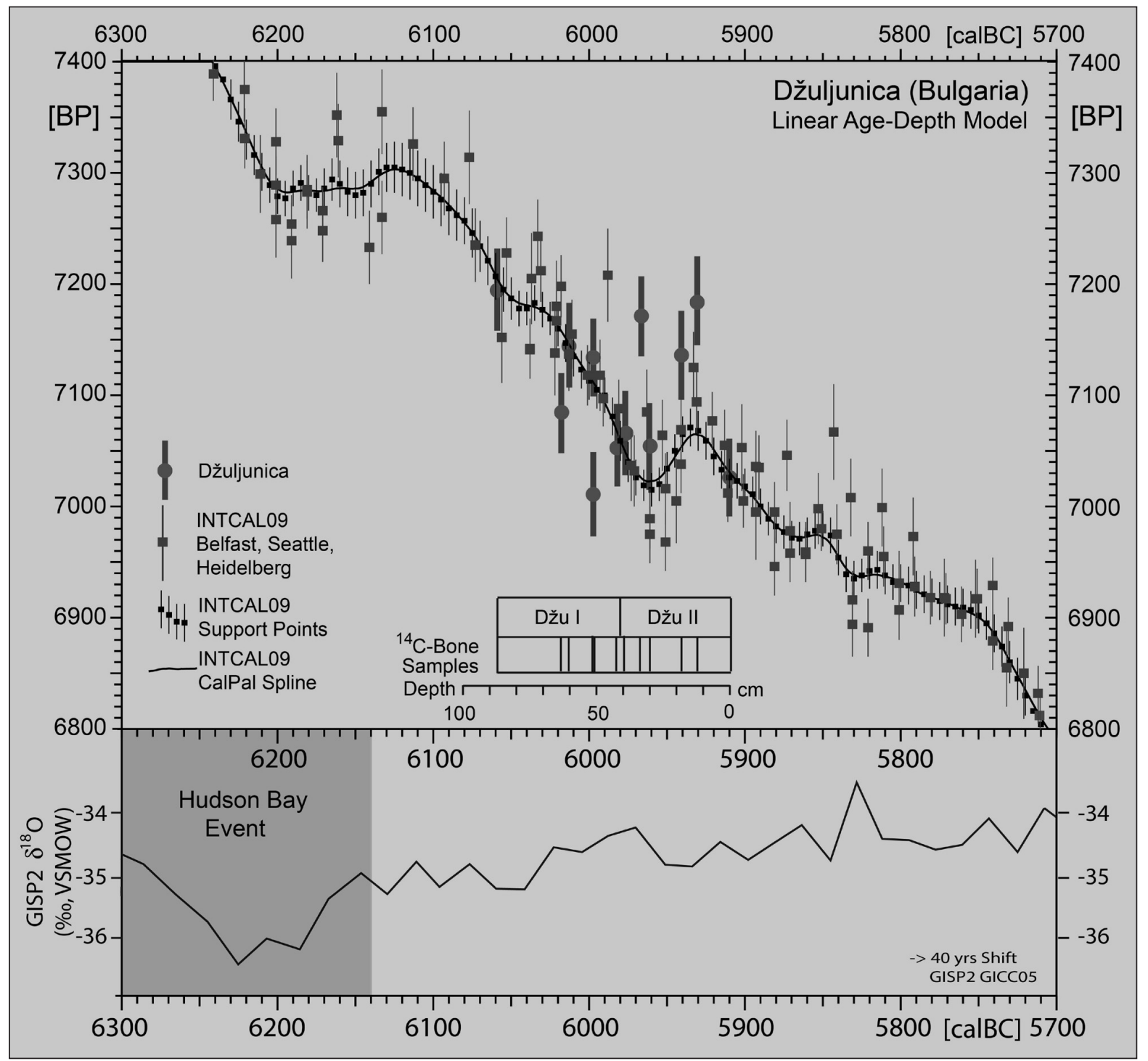

Fig. 16. (Upper): Džuljunica (NE-Bulgaria). Optimized Linear Stratigraphic Age model for Phases Dž I-II for average Growth-rate of $1.70 y r s / c m$, in comparison to INTCAL09 curve (Reimer et al. 2009), INTCAL09 high-precision calibration raw-data (Seattle/Heidelberg); (Lower): GISP2 8180 -record (Grootes et al. 1993) as proxy for North Atlantic ocean/atmosphere temperature with GISP2-ages shifted 40yrs younger according to Weninger and Jöris (2008) in agreement with GICC05-age model (Vinther et al. 2006). 14CData: see Krauß et al. (2014).

ver terrace above the Džuljunica River, which - together with other tributaries - flows into the Yantra River today at about $6.5 \mathrm{~km}$ north of the settlement.

Finds from the oldest settlement layer at Džuljunica (Dž-I) attest to clear similarities with material of the West Anatolian Late Neolithic. As such, pottery from this level is coeval with the very beginning of its usage in the Southeast European Neolithic cultural sequence. Furthermore, this earliest pottery (Dž-I) is comparable with assemblages from the near vicinity, including the oldest material from Koprivec and Pomoštica, as well as with vessels from Orlovec and Poljanica-Platoto. Similar vessel forms have also been recovered from Hotnica-Pešterata, but this material most probably represents a transition from Dž-I to Dž-II. Convincing parallels are attested in assemblages from West Anatolia, especially in the Izmir region, specifically Ulucak Va and early IV, Cukuriçi Höyük, and Yeşilova. Further details and references, in particular for the construction and interpretation of the ${ }^{14} \mathrm{C}$-age-depth model for Džuljunica phases I and II (Fig. 16), are presented by Raiko Krauß et al. (2014).

What is important is that, (1) the ${ }^{14} \mathrm{C}$-dates based on stratigraphic ${ }^{14} \mathrm{C}$-age modelling for the different sites are consistent with the respective pottery synchro- 
nisms in each case at phase level, and (2) the date of 6050 calBC achieved for the incipient occupation at Džuljunica (Dž-I) represents, to the present stateof-knowledge, the very earliest Neolithic known from anywhere in Southeast Europe outside the Aegean. New radiocarbon dates from the old excavations in Koprivec measured on cattle bones confirm that Neolithic settlement in that particular region does not begin before Džuljunica (Scheu et al. forthcoming).

\section{Conclusions}

Beginning with the Pre-Pottery-Neolithic ( 7500 calBC: Anatolian nomenclature. Fig. 4), the long-distance dispersal of Neolithic lifestyles from the Near East to Southeast Europe appears to have been established in a stepwise manner. Here we have focussed on achieving high-resolution dates for the introduction of farming in the circum-Aegean regions and its further dispersal into Southeast Europe. For arrival and dispersal, we distinguish two major chronological steps. The first comprises a land-based dispersal of the Neolithic from Central Anatolia to the Aegean and southern Marmara region, and probably - also by the sea-based coastal route from the Near East. This first step, which dates (abbreviated) to $\sim 6600$ calBC (i.e. the onset of RCC-conditions) appears to have been consolidated within a few decades, although this remains to be validated. The second step took Neolithic lifestyles away from the Aegean littoral all the way to north-eastern Hungary, Starting at $\sim 6050$ calBC (i.e. towards the end of RCC-conditions); this step was completed within 200 years. We infer that these processes can partly be explained by a mitigation of climate-induced biophysical and social hazards.

\section{Time-scales and terminology}

The age-models and chronologies discussed in this paper are based on tree-ring calibrated ${ }^{14} \mathrm{C}$-ages. $\mathrm{Nu}$ meric ages are given on the calendric time scale using [calBP or calBC/AD] units, with AD1950 $=0$ calBP as a reference year, using CalPal software (Weninger et al. 2008) and the INTCAL09 data set (Reimer et al. 2009). All GISP2-ages are shifted 40yrs younger than published (Grootes et al. 1993), according to Bernhard Weninger and Olaf Jöris (2008). By this procedure, annual agreement with the recounted Greenland ice-core GICC05 age model (Vinther et al. 2006) is achieved. Calibrated numeric ${ }^{14} \mathrm{C}$ age values are based on optimised (shortest) 95\% cal-scale intervals $[a, b]$, as calculated from the calibrated age-distributions, then re-scaled to provide a calibrated median [defined as $(\mathrm{a}+\mathrm{b}) / 2$ ] and a calibrated ' \pm ' value (approx. 68\%) [defined as (a-b)/ $2]$. This notation (applied in Figs. 1 and 4) is convenient for the purposes of numeric abbreviation (for tabulated calibrated ${ }^{14} \mathrm{C}$-ages), as well as providing room for further graphic contextualisation (e.g., representation of large amounts of site data and/or reference to climate records). The method is derived from probabilistic Dispersion-Calibration (Weninger 1980), simply, by showing only the calibrated median values and leaving out the envelope curve. To minimise age-distortion due to the non-commutative properties of the calibration operator, this socalled 'bar-code' method is based on quantum-theoretical Bayesian procedures that utilise non-normalised probabilities (Weninger et al. 2011). The modelling results shown in Figure 12 (Ulucak), Figure 13 (Çukuriçi Höyük), Figure 14 (Barcin Höyük), Figure 15 (Dikili Tash), and Figure 16 (Džuljunica) were achieved by applying an automated version of the method called 'Optimizing Gaussian Monte Carlo Wiggle Matching' (oGMCWM) described in Benz et al. (2012). CalPal-internally all numeric calculations have annual precision. With the exception of oGMCWM, this reduces to decadal precision for program-external comparisons (e.g., with $0 x \mathrm{Cal}$ or CALIB).

$$
\therefore
$$

All ${ }^{14} \mathrm{C}$-dates used in this paper are available from: https://uni-koeln.academia.edu/BernhardWeninger/ CalPal

ACKNOWLEDGEMENTS

We are grateful to Deng Hui (University of Peking, Beijing, China) for providing numeric data (Fig. 7). Special thanks are also due to Amit Tubi and Uri Dayan (University of Jerusalem, Israel) for information relating to the meteorology of Rapid Climate Change. We thank Zoi Tsirtsoni (Labex DynamiTe Research Group, Paris, France) for important geo-archaeological information pertaining to the sites at Dikili Tash and Sidari. Research at Cukuriçi Höyük is funded by the European Research Council (ERC project Prehistoric Anatolia 263339) and supported by the Austrian Science Fund (FWF project Y 528). Research at Barcin Höyük is funded by NWO, the Netherlands Organization for Scientific Research. 


\section{References}

Abu-Zied R. H., Rohling E. J., Jorissen F. J., Fontanier C., Casford J. S. L. and Cooke S. 2008. Benthic foraminiferal response to changes in bottom water oxygenation and organic carbon flux in the eastern Mediterranean during LGM to Recent times. Marine Micropaleontology 67: 46-68.

Akkermans P. M. M. G., Cappers R., Cavallo C. and Nieuwenhuyse 0. 2006. Investigating Early Pottery Neolithic of Northern Syria: New Evidence from Tell Sabi Abyad. American Journal of Archaeology 110: 123-156.

Ammerman A. J., Cavalli-Sforza L. L. 1971. Measuring the rate and spread of early farming in Europe. Man 6: 784688.

Aura Tortosa J. E., Jordá Pardo J. F., Pérez Ripoll M., Morales Pérez J. V., García Puchol 0., González-Tablas Sastre J. and Avezuela Aristu B. 2009. Epipaleolítico y Mesolítico en Andalucía oriental. Primeras notas a partir de los datos de la Cueva de Nerja (Málaga, España). In M. P. Utrilla Miranda, L. Montes Ramírez (eds.), El mesolítico geométrico en la Península Ibérica. Monografías Arqueológicas 44. Universidad de Zaragoza. Zaragoza: 343-360.

Ashmore P. 1999. Single entity dating. Mémoires de la Société préhistorique française 26: 65-71.

Balossi F. 2004. New Data for the Definition of the DFBW Horizon and Its Internal Developments. Anatolica 30: 109-149.

Bartl K. 2010. Shir, West Syria. Neo-Lithics 1(10): 92-93.

Begzsuren S., Ellis J. E., Ojima D. S., Coughenour M. B. and Chuluun T. 2004. Livestock Responses to Droughts and Severe Winter Weather in the Gobi Three Beauty National Park, Mongolia. Journal of Arid Environments 59(4): 785-796.

Benz M., Coşkun A., Hajdas I., Deckers K., Riehl S., Alt K. A., Weninger B. and Özkaya V., 2012. Methodological Implications of New Radiocarbon Dates from the Early Holocene Site of Körtik Tepe, Southeast Anatolia. Radiocarbon 54(3-4): 291-304.

Berger J-F., Garyfalia G., and Guilaine J. 2014. Vers une révision de la transition méso-néolithique sure le site de Sidari (Corfou, Grèce). Nouvelles données géoarcheologiques et radiocarbon, évaluation des processus post-dépositioneles. In C. Manen, T. Perrin and J. Guilaine (eds.), $L a$ Transition Néolithique en Méditerranée. Actes du colloque Transitions en Méditerranée, ou comment des chasseurs devinrent agriculteurs, Muséum de Toulouse, 14-15 avril 2011. Diffusion Erran. Errance. Arles at Toulouse: 209-228.
Biagi P., Shennan S. and Spataro M. 2005. Rapid Rivers and Slow Seas? New data for the radiocarbon chronology of the Balkan Peninsula. In L. Nikolova, J. Higgins (eds.), Prehistoric Archaeology and Anthropological Theory and Education. Reports of Prehistoric Research Projects 6-7: 43-51.

Biagi P. and Spataro M., 2005. New Observations on the Radiocarbon Chronology of the Starčevo-Criş and Körös Cultures. In L. Nikolova, J. Higgins (eds.), Prehistoric Archaeology and Archaeological Theory and Education. Reports of Prehistoric Research Projects 6-7. International Institute of Anthropology. Argosy University. Salt Lake City: 35-52.

Bocquet-Appel J. P., Naji S., Vander Linden M. and Kozłowski J. 2012. Understanding the rates of expansion of the farming system in Europe. Journal of Archaeological Science 39(2):5 31-546.

Bogdanović M. 2008. Grivac: Settlements of Proto-Starčevo and Vinča Culture. Center for Scientific Research of Serbian Academy of Sciences and Arts and University of Kragujevac and Natinal Museum of Kragujevac. Kragujevac.

Böhner U., Schyle D. 2009. Radiocarbon Context Database 2002-2006. DOI:10.1594/GFZ.CONTEXT.Ed1. Online http://context-database.uni-koeln.de/download.php

Borić D. 2011. Adaptations and Transformations of the Danube Gorges Foragers (c. 13.000-5500 BC): An Overview. In R. Krauß (ed.), Beginnings - New Research in the Appearance of the Neolithic Between Northwest Anatolia and the Carpathian Basin. Papers of the International Workshop $8^{\text {th-9th }}$ April 2009, Istanbul. Organized by D. Ciobotaru, B. Horejs and R. Krauß. Menschen-KulturenTraditionen. Studien aus den Forschungsclustern des Deutschen Archäologischen Instituts. Band 1. Deutsches Archäologischen Institut. Verlag Marie Leidorf GmbH. Rahden/Westf.: 157-203.

Breunig P. 1987. ${ }^{14} \mathrm{C}$-Chronologie des vorderasiatischen, südosteuropäiscehen und mitteleuropäischen Neolithikums. Monographien zur Urgeschichte. Reihe Fundamenta A13. Böhlau Verlag. Köln.

Brami M. N. 2014. A graphical simulation of the 2,000year lag in Neolithic occupation between Central Anatolia and the Aegean basin. Archaeological and Anthropological Sciences 6. doi: 10.1007/s12520-014-0193-4.

Brami M., Heyd V. 2011. The Origins of Europe's First Farmers: The Role of Hacilar and Western Anatolia, Fifty Years On. Prähistorische Zeitschrift 86: 165-206. 
Bronk Ramsey C. 2009. Bayesian analysis of radiocarbon dates. Radiocarbon 51(1): 337-60.

Cacho I., Grimalt J. O., Canals M., Sbaffi L., Shackleton N. J., Schoenfeld J. and Zahn R. 2001. Variability of the western Mediterranean Sea surface temperature during the last 25,000 years and its connection with the Northern Hemisphere climatic changes. Paleoceanography 16(1): 40-52.

Carvalho A. F. 2010. La passage vers l'Atlantique: le processus de néolithisation en Algarve (sud du Portugal). L'Anthropologie 114: 141-178.

Çakırlar C. 2012a. Neolithic Dairy Technology at the European-Anatolian Frontier: Implications of Archaeozoological Evidence from Ulucak Höyük, İzmir, Turkey, ca. 7000-5700 cal. BC. Anthropozoologica 47(2): 79-100.

2012b. The evolution of animal husbandry in Neolithic central-west Anatolia: the zooarchaeological record from Ulucak Höyük (c. 7040-5660 cal:BC, Izmir, Turkey. Anatolian Studies 62: 1-33.

Caneva I., Köroğlu G. 2010. Yumuktepe. A Journey Through Nine Thousand Years. Ege Yayinlari. Istanbul.

Casford J. S. L., Rohling E. J., Abu-Zied R., Fontanier C., Jorissen F. J., Leng M. J., Schmiedl G. and Thomson J. 2003. A Dynamic Concept for Eastern Mediterranean Circulation and Oxygenation During Sapropel Formation. Palaeogeography, Palaeoclimatology, Palaeoecology 190: 103-119.

Cheng H., Fleitmann D., Edwards R. L., Wang X., Cruz F. W., Auler A. S., Mangini A., Wang Y., Kong X., Burns S. J. and Matter A. 2009. Timing and structure of the $8.2 \mathrm{kyr}$ B.P. event inferred from $\delta 180$ records of stalagmites from China, Oman, and Brazil. Geology 37: 1007-1010.

Cheng H., Sinha A., Wang X., Cruz F. W. and Edwards R. L. 2012. The Global Paleomonsoon as seen through speleothem records from Asia and the Americas. Climate Dynamics 39: 1045-1062.

Çilingiroğlu C.. 2005. The concept of the "Neolithic Package": considering its meaning and applicability. Documenta Praehistorica 32: 1-13.

2009. Central-West Anatolia at the End of the $7^{\text {th }}$ and Beginning of $\sigma^{\text {th }}$ Millennium BCE in the Light of Pottery from Ulucak (izmir). PhD thesis. University of Tübingen. Online http://tobias-lib.ub.uni-tuebingen.de/vol ltexte/2009/4278/

2010. The Appearance of Impressed Pottery in the Neolithic Aegean and its Implications for Maritime Networks in the Eastern Mediterranean. Türkiye Bilimler Akademisi-AR (TÜBA-AR) 13: 9-22.
2011. The Current State of Neolithic Research at Ulucak, Izmir. In R. Krauß (ed.), Beginnings - New Research in the Appearance of the Neolithic between Northwest Anatolia and the Carpathian Basin. Papers of the International Workshop $8^{\text {th- }}$ th $^{\text {th }}$ April 2009, Istanbul. Organized by Dan Ciobotaru, Barbara Horejs and Raiko Krauß. Menschen-Kulturen-Traditionen. Studien aus den Forschungsclustern des Deutschen Archäologischen Instituts. Band 1. Verlag Marie Leidorf GmbH. Rahden/Westf.: 67-76.

2012. The Neolithic Pottery of Ulucak in Aegean Turkey. Organization of production, interregional comparisons and relative chronology. British Archaeological Reports IS 2426. Archaeopress. Oxford.

Çilingiroğlu A., Cevik 0. and Çilingiroğlu Ç. 2012. Towards Understanding the Early Farming Communities of Middle West Anatolia. In M. Özdoğan, N. Başgelen, and P. Kuniholm (eds.), The Neolithic in Turkey. New Excavations and New Research. Western Turkey. Archaeology \& Art Publications. Istanbul: 139-175.

Clare L. 2013. Culture Change and Continuity in the Eastern Mediterranean and During Rapid Climate Change. Assessing the Vulnerability of Neolithic Communities to a Little Ice Age in the Seventh Millennium calBC. Unpublished $\mathrm{PhD}$ thesis. University of Cologne. Cologne.

Clare L., Rohling E. J., Weninger B. and Hilpert J. 2008. Warfare in Late Neolithic/Early Chalcolithic Pisidia, southwestern Turkey. Climate induced social unrest in the late 7th millennium calBC. Documenta Praehistorica 35: 65-92.

Clare L., Weninger B. 2014 (in press). The dispersal of Neolithic lifeways: absolute chronology and rapid climate change. In M. Özdoğan, P. Kuniholm (eds.), The Neolithic in Turkey, new excavations and new research. Vol 6. Archaeology \& Arts Publications. Istanbul.

Clark J. G. D. 1965. Radiocarbon dating and the expansion of farming culture from the Near East over Europe. Proceedings of the Prehistoric Society 1: 58-73.

Cohen J., Saito K. and Entekhabi D. 2001. The Role of the Siberian High in Northern Hemisphere Climate Variability. Geophysical Research Letters 28(2): 299-302.

Contreras D. A., Meadows J. 2014. Summed radiocarbon calibrations as a population proxy: a critical evaluation using a realistic simulation approach. Journal of Archaeological Science 52: 591-608.

Cortés Sánchez M. and 22 co-authors 2012. The MesolithicNeolithic transition in southern Iberia. Quaternary Research 77: 221-234. 
Crombé P., Robinson E. 2014. ${ }^{14} \mathrm{C}$ dates as demographic proxies in Neolithisation models of Northwestern Europe: a critical assessment using Belgium and northeast France as a case-study. Journal Archaeological Science Volume 52: $558-56$.

Cruells W. 2008. The Proto-Halaf: Origins, definition, regional framework and chronology. In J. Ma Córdoba, M. Molist, Ma C. Pérez, I. Rubio and S. Martínez (eds.), Proceedings of the $5^{\text {th }}$ International Congress on the Archaeology of the Ancient Near East. Actas del V Congreso Internacional de Arqueología del Oriente Próximo Antiguo. Vol. III. Madrid: 671-689.

Darcque P., Koukouli-Chryssanthaki H., Malamidou D. and Zsirtoni Z. 2009. Rapport sur les traveaux de l'École francaise d'Athènes en 2008: Dikili Tash. Bulletin de Correspondence Hellénique 133: 529-541.

Düring B. S. 2013. Breaking the Bond: Investigating the Neolithic Expansion in Asia Minor in the Seventh Millennium BC. Journal of World Prehistory 26: 75-100.

Erdoğu B. 2013. Uğurlu: A Neolithic settlement on the Aegenan Island of Gökçeada. In M. Özdoğan, N. Başgelen and P. Kuniholm (eds.), The Neolithic in Turkey. New Excavations and New Research. Vol. 5 Northwestern Turkey and Istanbul. Archaeology and Art Publications. Istanbul: $1-33$.

Feurdean A., Klotz S., Mosbrugger V. and Wohlfarth B. 2008. Pollen-based Quantitative Reconstructions of Holocene Climate Variability in NW Romania. Palaeogeography, Palaeoclimatology, Palaeoecology 260(3-4): 494504.

Fleitmann D., Burns S. J, Mangini A., Mudelsee M., Kramers J., Villa I., Neff U., Al-Subbary A. A., Buettner A., Hippler D. and Matter A. 2007. Holocene ITCZ and Indian monsoon dynamics recorded in stalagmites from Oman and Yemen (Socotra). Quaternary Science Reviews 26: 170-188. doi:10.1016/j.quascirev.2006.04.012.

Fleitmann D., Cheng H., Badertscher S., Edwards R. L., Mudelsee M., Göktürk O. M., Fankhauser A., Pickering R., Raible C. C., Matter A., Kramers J. and Tüysüz 0. 2009. Timing and Climatic Impact of Greenland Interstadials Recorded in Stalagmites from Northern Turkey. Geophysical Research Letters 36(19): L19707. doi:10.1029/2009GL040 050.

Fletcher W. J., Sanchez Goñi M. F. 2008. Orbital- and suborbital-scale climate impacts on vegetation of the western Mediterranean basin over the last 48,000 yr. Quaternary Research 70(3): 451-464.

Forenbaher S., Miracle P. T. 2005. The spread of farming in the Eastern Adriatic. Antiquity 79(305): 514-528.
Forenbaher S., Kaiser T. and Miracle P. T. 2013. Dating the East Adriatic Neolithic. European Journal of Archaeology 16(4): 589-609.

Furholt M., Müller J., Raetzel-Fabian D., Rinne C. and Wotzka H-P. 2009. RADON. Datenbank mitteleuropäischer ${ }^{14} \mathrm{C}$-Daten für das Neolithikum und die frühe Bronzezeit. Online http://www.jungsteinsite.uni-kiel.de/radon/radon_ neu.htm.

Galik A., Horejs B. 2011. Çukuriçi Höyük - Various Aspects of Its Earliest Settlement Phase. In R. Krauß (ed.), Beginnings - New Research in the Appearance of the Neolithic Between Northwest Anatolia and the Carpathian Basin. Papers of the International Workshop $8^{\text {th }}$ 9th April 2009, Istanbul. Organized by D. Ciobotaru, B. Horejs and R. Krauß. Menschen-Kulturen-Traditionen. Studien aus den Forschungsclustern des Deutschen Archäologischen Instituts. Band 1. Deutsches Archäologischen Institut. Verlag Marie Leidorf GmbH. Rahden/Westf.: 83-94.

Gebel H. G. K. 2004. Central to What? The Centrality Issue of the LPPNB Mega-Site Phenomenon in Jordan. In H. D. Bienert, H. G. K. Gebel and R. Neef (eds.), Central Settlements in Neolithic Jordan. Proceedings of a Symposium Held in Wadi Musa, Jordan, 21st-25th of July 1997. Studies in Early Near Eastern Production, Subsistence, and Environment 5. Ex Oriente. Berlin: 1-19.

Gebel H. G. K. 2009. The Intricacy of Neolithic Rubble Layers. The Ba'ja, Basta, and 'Ain Rahub Evidence. Neo- $\mathrm{L} i$ thics 1(09): 33-48.

Gerritsen F. A., Özbal R. and Thissen L. 2013a. Barcın Höyük. The Beginnings of Farming in the Marmara Region. In M. Özdoğan, N. Başgelen and P. Kuniholm (eds.), The Neolithic in Turkey. New Excavations and New Research. Vol. 5. Northwestern Turkey and Istanbul. Archaeology and Art Publications. Istanbul: 93-112.

2013b. The Earliest Neolithic Levels at Barcın Höyük, Northwestern Turkey. Anatolica 39: 53-92.

Görsdorf J., Bojadžiev J. 1996. Zur absoluten Chronologie der bulgarischen Urgeschichte. Eurasia Antiqua 2: 105173 .

Groenhuijzen M., Kluiving S., Gerritsen F. and Künzel M. in prep. Geoarchaeological research at Barcin Höyük: implications for the initial Neolithic occupation of northwest Anatolia. Quarternary International.

Grootes P. M., Stuiver M., White J. W. C., Johnson S. and Jouzel J. 1993. Comparison of Oxygen Isotope Records from the GISP2 and GRIP Greenland Ice Cores. Nature 366: 552-554. 
Guilaine J. 2001. La diffusion de l'agriculture en Europe: une hypothèse arythmique. Zephyrus 53(4): 267-272.

2003. De la vague à la tombe. La conquête néolithique de la Méditerranée (8000-2000 avant J.-C.). Le Seuil. Paris

2013. The Neolithic Transition in Europe: some Comments on Gaps, Contacts, Arrhythmic Model, Genetics. In E. Starnini (ed.), Unconformist Archaeology. Papers in honour of Paolo Biagi. British Archaeological reports IS 2528. Archaeopress. Oxford: 55-64.

Hinz M., Feeser I., Sjögren K-G. and Müller J. 2012. Demography and the intensity of cultural intensities: an evaluation of Funnel Beaker Societies (4200-2800 calBC). Journal of Archaeological Science 39(10): 3331-3340.

Horejs B. 2010. Çukuriçi Höyük. Neue Ausgrabungen bei einem Tell bei Ephesus. In S. Aybek, A. Kazım Öz (eds.), The Land of the Crossroads. Essays in Honour of Recep Meriç. Metropolis Ionia II. Istanbul: 167-175.

2012. Çukuriçi Höyük. A Neolithic and Bronze Age Settlement in the Region of Ephesos. In M. Özdoğan, N. Başgelen and P. Kuniholm (eds.), The Neolithic in Turkey. New Excavations and New Research. Vol. 4. Western Turkey. Archaeology \& Art Publications. Istanbul: 117-131.

Horejs B., Weninger B. in prep. Zur Radiocarbondatierung des frühen und späten Chalkolithikums am Çukurici Höyük. In B. Horejs (ed.), Cukuriçi Höyük 1. Erste Ergebnisse zum frühen und späten Chalkolithikum. Vienna.

Josey S. A., Somot S. and Tsimplis M. 2011. Impacts of atmospheric modes of variability on Mediterranean Sea surface heat exchange. Journal of Geophysical Research 116. C02032. doi:10.1029/2010JC006685.

Karul. N., Avcı M. B. 2013. Aktopraklık. In M. Özdoğan, N. Başgelen and P. Kuniholm (eds.), The Neolithic in Turkey. New Excavations and New Research. Vol. 5 Northwestern Turkey and Istanbul. Archaeology and Art Publications. Istanbul: 45-68.

Kiziltan Z., Polat M. A. 2013. The Neolithic at Yenikap1 Marmaray-Matro Project Rescue Excavations. In M. Özdoğan, N. Başgelen and P. Kuniholm (eds.), The Neolithic in Turkey. New Excavations and New Research. Vol. 5 Northwestern Turkey and Istanbul. Archaeology and Art Publications. Istanbul: 113-165.

Klitgaard-Kristensen D., Sejrup H. P., Haflidason H., Johnsen S. and Spurk M. 1998. A regional 8200 cal. yr BP cooling event in northwest Europe, induced by final stages of the Laurentide ice-sheet deglaciation? Journal Quaternary Science 13(2): 165-169.
Koukouli-Chryssanthaki H., Treuil R., Lespez L. and Malamidou D. (eds.) 2008. Dikili Tash, village préhistorique de Macédoine orientale. Recherches franco-helléniques dirigées par la Société Archéologique d'Athènes et l'école française d'Athènes (1986-2001). Bibliothèque de la Société Archéologique d'Athènes $n^{\circ} 254$. Athènes.

Krauß R., Elenski N., Weninger B., Clare L., Cakırlar C. and Zidarov P. 2014. Beginnings of the Neolithic in Southeast Europe. The Early Neolithic sequence and absolute dates from Džuljunica-Smărdeš (Bulgaria). Documenta Praehistorica 41.

Lau N. C., Lau K.-M. 1984. Structure and Energetics of Midlatitude Disturbances Accompanying Cold Air Outbreaks over East Asia. Monthly Weather Review 112(7): 13091327.

Lemmen C., Gronenborn D. and Wirtz K. W. 2011. A simulation of the Neolithic transition in Western Eurasia. Journal of Archaeological Science 38: 3459-3470.

Lemmen C., Wirtz K. W. 2012. On the sensitivity of the simulated European Neolithic transition to climate extremes. Journal of Archaeological Science 38: 65-72.

Lespez L., Tsirtsoni Z., Darcque P., Koukouli-Chryssanthraki H., Malamidou D., Treuil R. and Oberlin C. 2013. The lowest levels at Dikili Tash, northern Greece: a missing link in the Early Neolithic of Europe. Antiquity 87: 30-45.

Lichardus-Itten M., Demoule J.-P., Perničeva L., GrebskaKulova M. and Kulov I. 2002. The site of Kovačevo and the beginnings of the Neolithic period in southwestern Bulgaria. The French-Bulgarian excavations 1986-2000. In M. Lichardus-Itten, J. Lichardus and V. Nikolov (eds.), Beiträge zu jungsteinzeitlichen Forschungen in Bulgarien. Saarbrücker Beiträge zur Altertumskunde 74. Dr. Rudolf Habelt Gmbh. Bonn: 99-158.

Linick T. 1977. La Jolla Natural Radiocarbon Measurements VII. Radiocarbon 19(1): 19-48.

Linstädter J., Medved I., Solich M. and Weniger G.-C. 2012. Neolithisation process within the Alboran territory: Models and possible African impact. Quaternary International 274: $219-232$.

Linstädter J., Kehl M. 2012. The Holocene archaeological sequence and site formation processes at Ifri Oudadane, NE Morocco. Journal of Archaeological Science 39: 33063323.

Linstädter J. in press. Climate induced mobility and the missing Middle Neolithic of Morocco. In M. Reindel (ed.), Palaeoenvironment and the Development of Early Societies. Proceedings of International workshop. Sanliurfa $5^{\text {th- }} 7^{\text {th }}$ October 2012. 
Liu Y-H., Henderson G. M., Hu C-Y., Mason A. J., Charnley N., Johnson K. R. and Xie S-C. 2013. Links between the East Asian Monsoon and North Atlantic Climate during the 8,200 year event. Nature Geoscience 6: 117-120.

Luca S. A, Diaconescu D. and Suciu C. I. 2008. Archaeological research in Miercurea Sibiului-Petriş (Sibiu Country Romania): the Starčevo-Criș level during 1997-2005 (a preliminary report). Documenta Praehistorica 35: 325343.

Luca S. A., Suciu C. 2006. Bazăde date deschisă(C14) pentru neoliticul şi eneoliticul din zona Carpato-Danubiă. In N. Ursulescu (ed.), Dimensiunea Europeană a Civilizatiei Eneolithitice Est-Carpatice. Universitatea "Alexandru Ioan Cuza". Centrul Interdisciplinar de Studii Arheoistorice. Editura Universităţii "Al. I. Cuza". Iași: 219-228.

Marino G., Rohling E. J., Sangiorgi F., Hayes A., Casford J. L., Lotter A. F., Kucera M. and Brinkhuis H. 2009. Early and Middle Holocene in the Aegean Sea: Interplay Between High and Low Latitude Climate Variability. Quaternary Science Reviews 28(27-28): 3246-3262.

Mayewski P., Meeker L. D., Twickler M. S., Whitlow S., Yang Q., Lyons W. B. and Prentice M. 1997. Major Features and Forcing of High Latitude Northern Hemisphere Circulation Using a 110,000-year-long Glaciochemical Series. Journal of Geophysical Research 102(C12): 2634526366.

Mayewski P. A. and 15 authors. 2004. Holocene Climate Variability. Quaternary Research 62: 243-255.

Meeker L. D., Mayewski P. A. 2002. A 1400-year High-resolution Record of Atmospheric Circulation over the North Atlantic and Asia. The Holocene 12(3): 257-266.

Mercone D., Thomson J., Abu-Zied R. H., Croudace I. W. and Rohling E. J. 2001. High-resolution geochemical and micropalaeontological profiling of the most recent eastern Mediterranean sapropel. Marine Geology 177: 25-44.

Migowski C., Stein M., Prasad S., Negendank J. F. W. and Agnon A. 2006. Holocene climate variability and cultural evolution in the Near East from the Dead Sea sedimentary record. Quaternary Research 66: 421-431.

Morales J., Pérez-Jordà G., Peña-Chocarro L., Zapata L., Ruíz-Alonso M., López-Sáez J. A. and Linstädter J. 2013. The origins of agriculture in North-West Africa: macro-botanical remains from Epipalaeolithic and Early Neolithic levels of Ifri Oudadane (Morocco). Journal of Archaeological Science 40(6): 2659-2669.

Oross K., Siklósi Z. 2012. Relative and absolute chronology of the Early Neolithic in the Great Hungarian Plain.
In A. Anders, Zs. Siklósi, (eds), The First Neolithic Sites in Central/South-East European Transect, Vol. III, The Körös Culture in Eastern Hungary. British Archaeological Reports IS 2334. Archaeopress. Oxford: 129-159.

Özbaşaran M. 2011. Re-Starting at Asıkl1. Anatolia Antiqua XIX: 27-37.

Özbaşaran M., Duru G. 2011. Akarçay Tepe. A PPNB and PN Settlement in Middle Euphrates - Urfa. In M. Özdoğan, N. Başgelen and P. Kuniholm (eds.), The Neolithic in Turkey. Vol. 2. The Euphrates Basin. Archaeology \& Art Publications. Istanbul: 165-202.

Özdoğan A. 1999. Çayönü. In M. Özdoğan, N. Başgelen (eds.), Neolithic in Turkey - The Cradle of Civilization. New Discoveries. Arkeoloji ve sanat yayinlari. Istanbul: 35-63.

Özdoğan M. 2013. Neolithic Sites in the Marmara Region: Fikirtepe, Pendik, Yarımburgaz, Toptepe, Hoca Çeşme and Aşağıpınar. In M. Özdoğan, N. Başgelen and P. Kuniholm (eds.), The Neolithic in Turkey. New Excavations and New Research. Vol. 5. Northwestern Turkey and Istanbul. Archaeology and Art Publications. Istanbul: 167-269.

Özdoğan M., Miyak Y. and Özbaşaran Dede N. 1991. An Interim Report on Excavations at Yarımburgaz and Toptepe in Eastern Thrace. Anatolica 17: 59-121.

Perlès C. 2005. From the Near East to Greece: let's reverse the focus. Cultural elements that didn't transfer. In C. Lichter (ed.), How Did Farming Reach Europe. AnatolianEuropean Relations from the Second Half of the $7^{\text {th }}$ through the First Half of the $6^{\text {th }}$ Millennium cal BC. Proceedings of the International Workshop Istanbul, 20-22 May 2004. BYZAS 2. Veröffentlichungen des Deutschen Archäologischen Instituts, 59-74. Yayinlari. Istanbul: 275290.

Perlés C., Quiles A. and Valladas H. 2013. Early seventhmillennium AMS dates from domestic seeds in the Initial Neolithic at Franchthi Cave (Argolid, Greece). Antiquity 87 (338): 1001-1015.

Pinardi N., Zavatarelli M., Adani M., Coppini G., Fratianni C., Oddo P., Simoncelli S., Tonani M., Lyubartsev V., Dobricic $S$. and Bonaduce A. 2013-14 (in press). Mediterranean Sea large-scale low-frequency ocean variability and water mass formation rates from 1987 to 2007: A retrospective analysis. Progress in Oceanography. http://dx. doi.org/10.1016/j.pocean.2013.11.003.

Pinhasi R., Fort J. and Ammerman A. J. 2005. Tracing the Origin and Spread of Agriculture in Europe. PLoS Biol 3 (12): e410. doi:10.1371/journal.pbio.0030410. 
Peyron O., Goring S., Dormoy I., Kotthoff U., Pross J., de Beaulieu J.-L., Drescher-Schneider R., Vannière B. and Magny M. 2011. Holocene seasonality changes in the central Mediterranean region reconstructed from the pollen sequences of Lake Accesa (Italy) and Tenaghi Philippon (Greece). The Holocene 2: 131-146.

Plug J., van der Plicht J. and Akkermans P. M. M. G. 2014. Tell Sabi Abyad: Dating of Neolithic Cemeteries. Radiocarbon 56(2): 543-554.

van der Plicht J., Akkermans P., Nieuwenhuyse O., Kaneda A. and Russell A. 2011. Tell Sabi Abyad, Syria: Radiocarbon Chronology, Cultural Change, and the $8.2 \mathrm{Ka}$ Event. Radiocarbon 53(2): 229.

Pross J., Kotthoff U., Müller U. C., Peyron O., Dormoy I., Schmiedl G., Kalaitzidis S. and Smith A. M. 2009. Massive Perturbation in Terrestrial Ecosystems of the Eastern Mediterranean Region Associated with the 8.2 Kyr BP Climatic Event. Geology 37(10): 887-890.

Quitta H. 1967. The C14 Chronology of the Central and SE European Neolithic. Antiquity 41(164): 263-270.

Reimer P. J. and 27 co-authors 2009. IntCal09 and Marine09 Radiocarbon Age Calibration Curves, 0-50,000 Years Cal BP. Radiocarbon 51: 1111-1150.

Reingruber A. 2011. Early Neolithic settlement patterns and exchange networks in the Aegean. Documenta Praehistorica 38: 291-305.

Reingruber A., Thissen L. 2004. CANeW ${ }^{14} \mathrm{C}$ databases and ${ }^{14} \mathrm{C}$ charts. Aegean Catchment (E Greece, S Balkans and W Turkey), 10,000-5500 calBC. Previously: www.canew. org.

Rohling E. J, Mayewski P., Abu-Zied R., Casford J. and Hayes A. 2002. Holocene Atmosphere-ocean Interactions: Records from Greenland and the Aegean Sea. Climate Dynamics 18(7): 587-593.

Rohling E. J., Mayewski P. A. and Challenor P. 2003. On the timing and mechanism of millennial-scale climate variability during the last glacial cycle. Climate Dynamics 20: $257-267$.

Rohling E. J, Pälike H. 2005. Centennial-scale Climate Cooling with a Sudden Cold Event around 8,200 Years Ago. Nature 434(7036): 975-979.

Rohling E. J., Abu-Zied R., Casford J. L., Hayes A. and Hoogakker B. A. A. 2009. The Marine Environment: Present and Past. In J. Woodward (ed.), The Physical Geography of the Mediterranean. Oxford University Press. Oxford: 33-68.
Rollefson G. 0. 2009. Slippery Slope: The Late Neolithic Rubble Layer in the Southern Levant. Neo-Lithics 1(09): 12-18.

Saaroni H., Bitan A., Alpert P. and Ziv B. 1996 Continental polar outbreaks into the Levant and eastern Mediterranean. International Journal of Climatology 16: 11751191.

Scheu A. et al. (forthcoming). The multifaceted origin of the Southeastern European Neolithic A synthesis of archaeology, archaeozoology and palaeogenetics.

Shennan S., Edinborough K. 2007. Prehistoric population history: from the Late Glacial to the Late Neolithic in Central and Northern Europe. Journal of Archaeological Science 34: 1339-1345.

Shennan S., Downey S. S., Timpson A., Edinborough K., Colledge S., Kerig T., Manning K. and Thomas M. G. 2013. Regional population collapse followed initial agriculture booms in mid-Holocene Europe. Nature Communications 4: $1-8$.

Silva F., Steele J. 2014. New Methods for Reconstructing Geographical Effects on Dispersal Rates and Routes from Large-Scale Radiocarbon Databases. Journal of Archaeological Science. doi: 10.1016/j.jas.2014.04.021.

Thomas E. R., Wolff E. W., Mulvaney R., Steffensen J. P., Johnsen S. J., Arrowsmith C., Whited J. W. C., Vaughn B. and Popp T. 2007. The $8.2 \mathrm{ka}$ event from Green-land ice cores. Quaternary Science Reviews 26: 70-81.

Tasić N. 1988. Comparative C-14 dates for the Neolithic Settlements in Serbia. In D. Srejović (ed.), The Neolithic of Serbia, Archaeological Research 1948-1988. University of Beograd. Beograd.

Treuil R. (ed.) 1992. Dikili Tash: village préhistorique de Macédoine Orientale I, Fouilles de Jean Deshayes (1961-1975). Bulletin de correspondance hellénique: Supplément. Ecole Française d'Athènes. Athènes.

Tsuneki A. 2010. A Newly Discovered Neolithic Cemetery at Tell el-Kerkh, Northwest Syria. In P. Matthiae, F. Pinnock, L. Nigro and N. Marchetti (eds.), Proceedings of the $6^{\text {th }}$ International Congress of the Archaeology of the Ancient Near East. 5 May - 10 May 2009, "Sapienza", Università Di Roma. Volume 2, Excavations, Surveys and Restorations. Reports on Recent Field Archaeology in the Near East. Harrassowitz Verlag. Wiesbaden: 697-713.

Tubi A., Dayan U. 2013. The Siberian High: Teleconnections, Extremes and Association with the Icelandic Low. International Journal of Climatology 33(6): 13571366. 
Vinther B. M., Clausen H. B., Johnsen S. J., Rasmussen S. O., Andersen K. K., Buchardt S. L., Dahl-Jensen D., Seierstad I. K., Siggaard-Andersen M.-L., Steffensen J. P., Svensson A. M., Olsen, J. and Heinemeier J. 2006. A synchronized dating of three Greenland ice cores throughout the Holocene. Journal Geophysical Research 111: D13102. doi:10.1029/2005JD006921.

Wang Y. J., Cheng H., Edwards R. L., An Z. S., Wu J. Y., Shen C. C. and Dorale J. A. 2001. A High-Resolution Absolute-Dated Late Pleistocene Monsoon Record from Hulu Cave, China. Science 294(5550): 2345-2348.

Wang Y., Cheng H., Edwards R.L., He Y., Kong X., An Z., Wu J., Kelly M. J., Dykoski C. A. and Li X. 2005. The Holocene Asian Monsoon: Links to Solar Changes and North Atlantic Climate. Science 308: 854-85.

Weninger B. 1986. High-precision calibration of archaeological radiocarbon dates. Acta Interdisciplinaria Archaeologica 4: 11-53.

2014. https://www.academia.edu/7138016/Europe. xls_-_CalPal-Format_14C-Database.

Weninger B., Alram-Stern E., Bauer E., Clare L., Danzeglocke U., Jöris 0., Kubatzki C., Rollefson G. O., Todorova H. and van Andel T. 2006. Climate Forcing Due to the 8200 calBP Event Observed at Early Neolithic Sites in the Eastern Mediterranean. Quaternary Research 66: 401-420.

Weninger B., Jöris 0. 2008. A 14C Age Calibration Curve for the Last $60 \mathrm{Ka}$ : The Greenland-Hulu U/Th Timescale and Its Impact on Understanding the Middle to Upper Paleolithic Transition in Western Eurasia. Journal of Human Evolution 55(5): 772-781.

Weninger B. and 18 co-authors. 2009a. The Impact of Rapid Climate Change on Prehistoric Societies during the Holocene in the Eastern Mediterranean. Documenta Praehistorica 36: 7-59.

Weninger B., Edinborough K., Bradtmöller M., Collard M., Crombé P., Danzeglocke U., Holst D., Jöris O., Niekus M. and Shennan S. 2009b. A Radiocarbon Database for the Mesolithic and Early Neolithic in Northwest Europe. In P. Crombé, M. van Strydonck, J. Sergant, M. Boudin and M. Bats (eds.), Chronology and Evolution within the Mesolithic of North-West Europe. Proceedings of an International Meeting, Brussels, May 30th-June 1st 2007. Cambridge Scholars Publishing. Newcastle upon Tyne: 143176.

Weninger B., Clare L. 2011. Holocene Rapid Climate Change in the Eastern Mediterranean: An Emerging Archaeological Climate Research Project. In K. Raiko (ed.), Beginnings - New Research in the Appearance of the Neolithic between Northwest Anatolia and the Carpathian Basin. Papers of the International Workshop $8^{\text {th }}$ 9th April 2009, Istanbul. Organized by D. Ciobotaru, B. Horejs and R. Krauß. Menschen-Kulturen-Traditionen. Studien aus den Forschungsclustern des Deutschen Archäologischen Instituts. Band 1. Deutsches Archäologischen Institut. Verlag Marie Leidorf GmbH. Rahden/Westf.: 11-22.

Weninger B., Edinborough K., Clare L. and Jöris 0. 2011. Concepts of Probability in Radiocarbon Analysis. Documenta Praehistorica 38:1-20.

Zapata L., López-Sáez J. A., Ruiz-Alonso M., Linstädter J., Pérez Jordà G., Morales J., Kehl M. and Peña-Chocarro L. 2013. Holocene environmental change in NE Morocco: Archaeological and Palaeobotanical evidences from Ifri Oudadane. The Holocene 23 (9): 1286-1296.

Zielhofer C., Clare L., Rollefson G. O., Wächter S., Hoffmeister D., Bareth G., Roettig C., Bullmann H., Schneider B., Berke H. and Weninger B. 2012. The Decline of the Early Neolithic Population Centre of 'Ain Ghazal and Corresponding Earth Surface Processes, Jordan Rift Valley. Quaternary Research 78: 427-441.

Zilhão J. 2001, Radiocarbon evidence for maritime pioneer colonization at the origins of farming in west Mediterranean Europe. Proceedings of the National Academy of Sciences USA 98(24): 14180-14185. 
